SANDIA REPORT

SAND98-1460

Unlimited Release

Printed July 1998
RECEIVED

JUL 27098

OSTI

Stabilization of In-Tank Residual Wastes

and External-Tank Soil Contamination for

the Tank Focus Area, Hanford Tank

Initiative: Applications to the AX Tank

Farm

Steven D. Balsley, James L. KrumhansI, David J. Borns, R. Gordon McKeen

Prepared by

Sandia National 1 aboratories

Albuquerque. New Mexico 87185 and Livermore, California 94550

Sandia is a nutiprogram laboratory operated by Sandia Corporation, a Lockheed Martin Company, for the United States Department of

Energy under Contract DE-AC04-94AL85000.

Approved for public release; further dissemination unlimited.

(17) Sandia National Laboratories 


\section{DISCLAIMER}

This report was prepared as an account of work sponsored by an agency of the United States Neither the United States Government nor any agency thereof, nor any of their Government. Neither the Unity, express or implied, or assumes any legal liability or responsiemployees, makes any warrant, exproduct, or

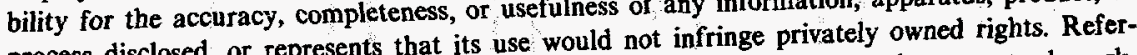
process disclosed, or represents that its use would process, or service by trade name, trademark, ence herein to any specific commercial produrily constitute or imply its endorsement, recommanufacturer, or otherwise does not necessanly constitute or any agency thereof. The views mendation, or favoring by the United States Government or ans state or reflect those of the and opinions of authors expressed herein do not necess United States Government or any agency thereof.

Issued by Sandia National Laboratories, operated for the United States Department of Energy by Sandia Corporation.

NOTICE: This report was prepared as an account of work sponsored by an agency of the United States Government. Neither the United States Government nor any agency thereof, nor any of their employees, nor any of their contractors, subcontractors, or their employees, makes any warranty, express or implied, or assumes any legal liability or responsibility for the accuracy, completeness, or usefulness of any information, apparatus, product, or process disclosed, or represents that its use would not infringe privately owned rights. Reference herein to any specific commercial product, process, or service by trade name, trademark, manufacturer, or otherwise, does not necessarily constitute or imply its endorsement, recommendation, or favoring by the United States Government, any agency thereof, or any of their contractors or subcontractors. The views and opinions expressed herein do not necessarily state or reflect those of the United States Government, any agency thereof, or any of their contractors.

Printed in the United States of America. This report has been reproduced directly from the best available copy.

Available to DOE and DOE contractors from

Office of Scientific and Technical Information

P.O. Box 62

Oak Ridge, TN 37831

Prices available from (615) 576-8401, FTS 626-8401

Available to the public from

National Technical Information Service

U.S. Department of Commerce

5285 Port Royal Rd

Springfield, VA 22161

NTIS price codes

Printed copy: A04

Microfiche copy: A01

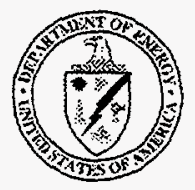




\section{DISCLAIMER}

Portions of this document may be illegible electronic image products. Images are produced from the best available original document. 
SAND98-1460

Unlimited Release

Printed July 1998

\title{
Stabilization of In-Tank Residual Wastes and External-Tank Soil Contamination For the Tank Focus Area, Hanford Tank Initiative: Applications to the AX Tank Farm
}

\author{
Steven D. Balsley* and James L. Krumhansl \\ Geochemistry Department \\ David J. Borns \\ Geophysical Technology Department \\ Sandia National Laboratories \\ P.O. Box 5800 \\ Albuquerque, NM 87185-0750 \\ R. Gordon McKeen \\ Alliance for Transportation Research \\ 1001 University Blvd. SE, Suite 103 \\ Albuquerque, NM 87106-4342
}

\begin{abstract}
A combined engineering and geochemistry approach is recommended for the stabilization of waste in decommissioned tanks and contaminated soils at the AX Tank Farm, Hanford, WA. A two-part strategy of desiccation and gettering is proposed for treatment of the in-tank residual wastes. Dry portland cement and/or fly ash are suggested as an effective and low-cost desiccant for wicking excess moisture from the upper waste layer. Getters work by either ion exchange or phase precipitation to reduce radionuclide concentrations in solution. We recommend the use of specific natural and man-made compounds, appropriately proportioned to the unique inventory of each tank. A filler design consisting of multilayered cementitous grout with interlayered sealant horizons should serve to maintain tank integrity and minimize fluid transport to the residual waste form. External tank soil contamination is best mitigated by placement of grouted skirts under and around each tank, together with installation of a cone-shaped permeable reactive barrier beneath the entire tank farm. Actinide release rates are calculated from four tank closure scenarios ranging from "no action" to a comprehensive stabilization treatment plan (desiccant/getters/grouting/RCRA cap). Although preliminary, these calculations indicate significant reductions in the potential for actinide transport as compared to the no-treatment option.
\end{abstract}

*Now in Analytical Services Department, MS 0871 


\section{ACKNOWLEDGEMENT}

Hank Westrich and Larry Bustard (both at Sandia) provided critical reviews of early versions of the report. Tom Burford (Sandia), Sam Bendamere (Denver Grouting, Inc.), John Case (Case \& Assoc.), Alan Kuhn, (AK Geoconsult. Co.) and Steven Phillips (AGEC, Inc.) supplied us with useful information and contacts regarding cement grout emplacement technologies, grout formulations and tank filling advice. Thanks to Ernst Ahrens (Sandia) for discussions about tank filler strategies and the use of micro-fine cement grouts. We also thank Dave Becker (Hanford) for technical discussions and Ed Fredenburg (Hanford) for programmatic advice, both of which helped establish the guidelines for this work, and clarified objectives for future research within the Tank Focus Area. Pat Brady and Harlan Stockman (Sandia) provided reviews that greatly improved the manuscript. 


\section{Contents}

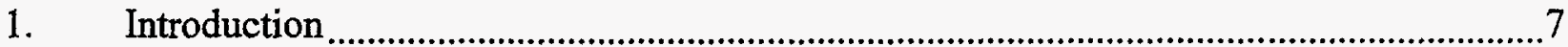

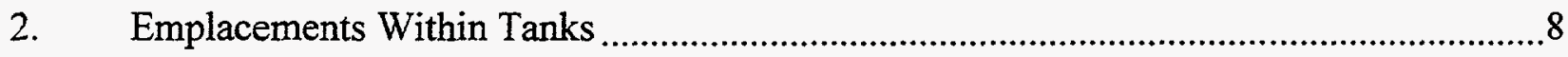

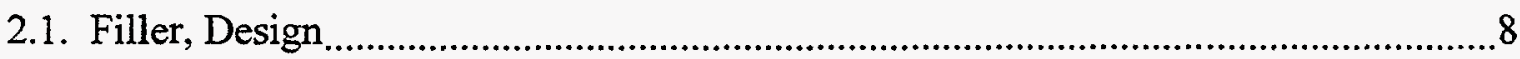

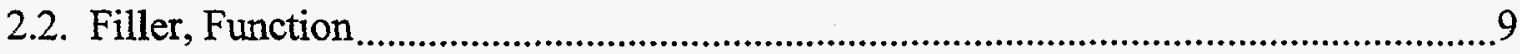

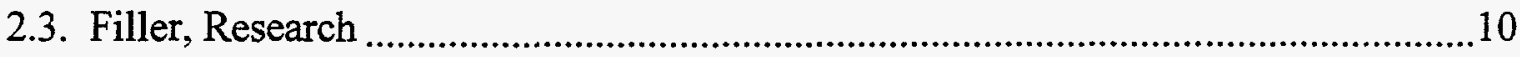

2.4. Waste horizon Treatment, Design ..........................................................................11

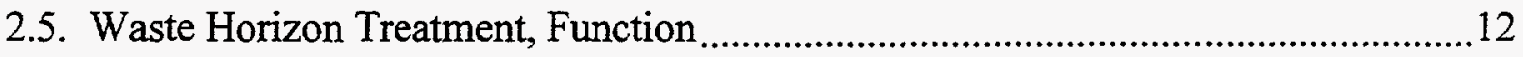

2.6. Waste Horizon Treatment, Research ......................................................................16

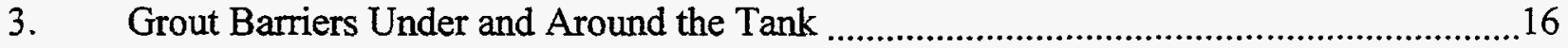

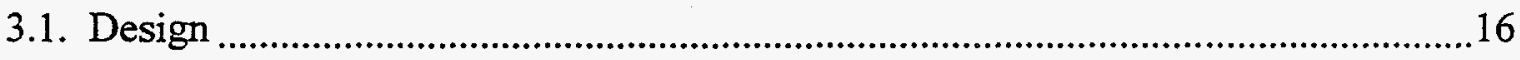

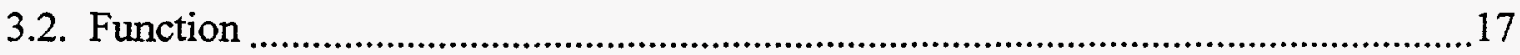

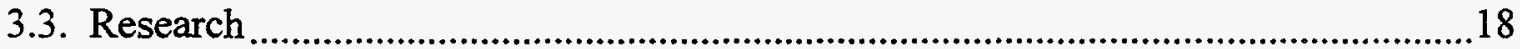

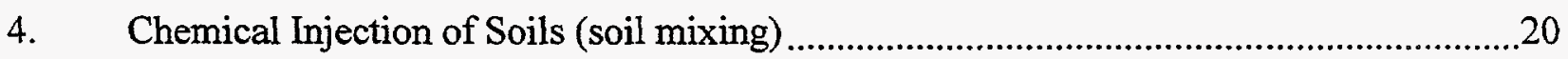

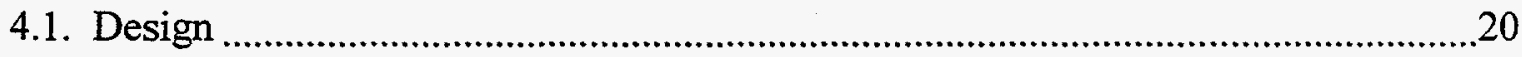

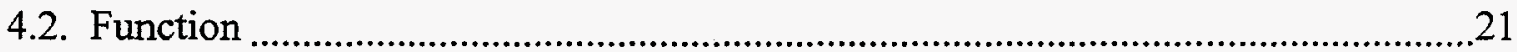

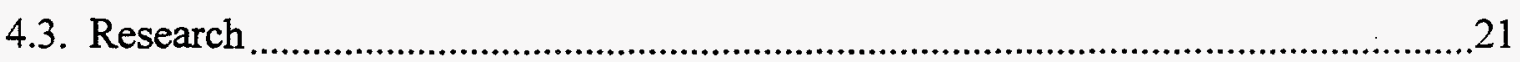

5. The explicit recognition of natural attenuation .......................................................22

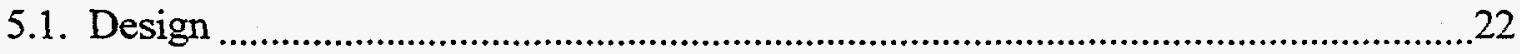

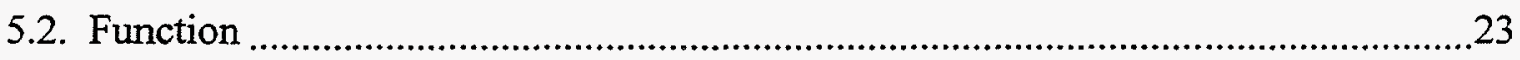

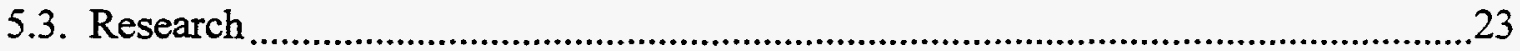

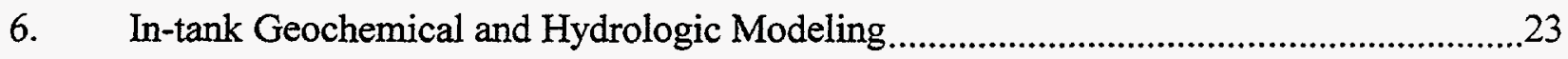

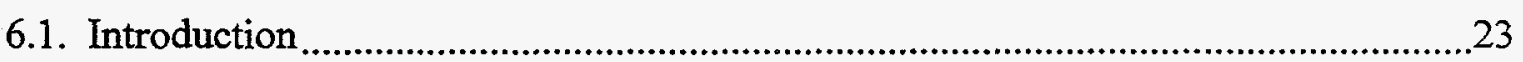

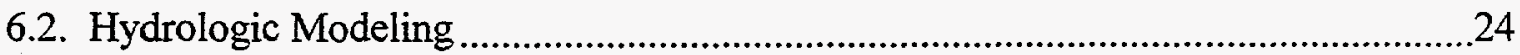

6.3. Infiltration rate

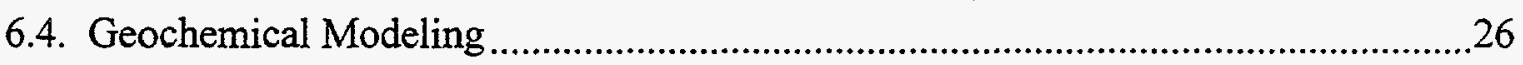

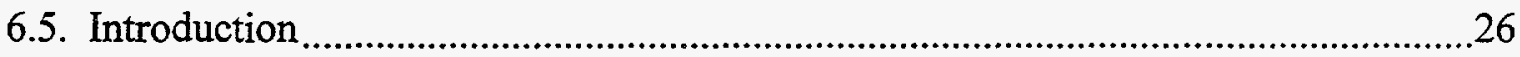

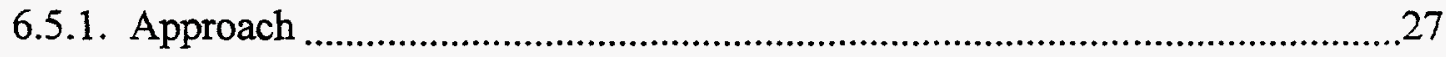

6.5.2. Baseline Solubility Calculations .................................................................2

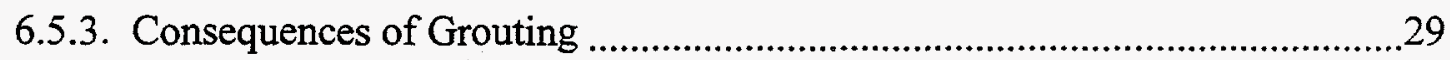


6.5.4. Consequences of Phosphate Addition

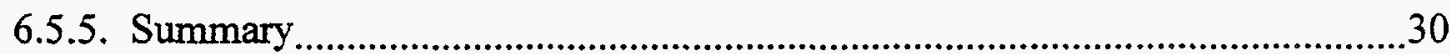

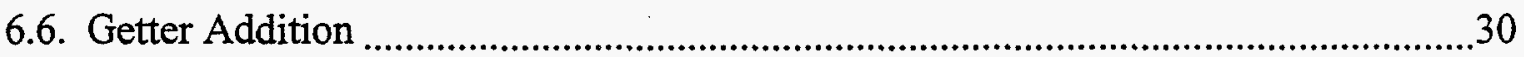

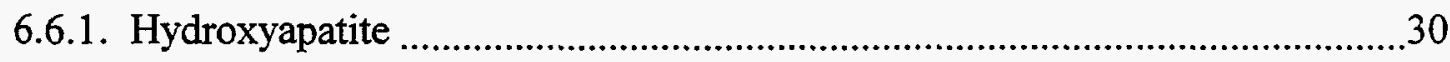

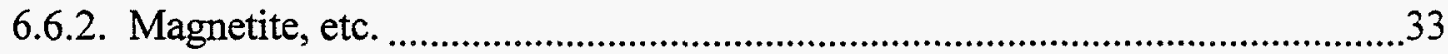

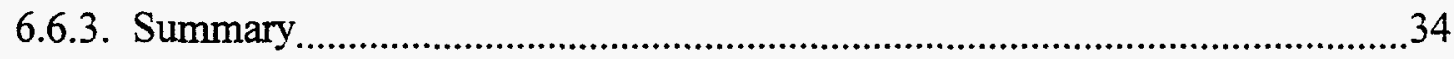

6.7. Radionuclide Release Models ....................................................................................34

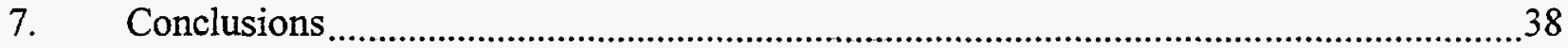

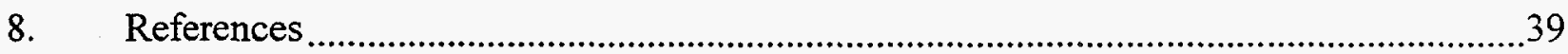

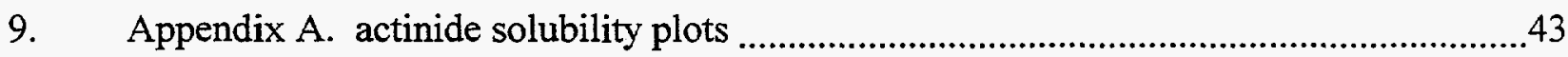

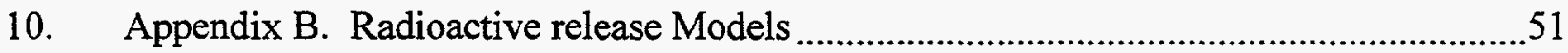

\section{Figures}

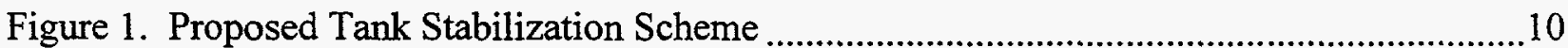

Figure 2. Conceptual Backfilled AX Tank and Underlying Cement Plug with Assumed Hydrologic Properties or Relationships.

\section{Tables}

1. Potential Getter Materials For Various Radionuclides ...............................................................13

2. Radionuclide Concentrations in Tank AX-102 Rinses ........................................................13

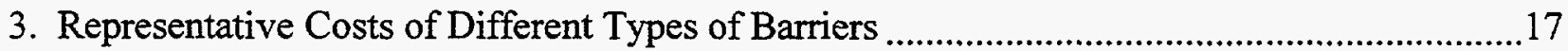

4. Trial Fluid Species and Concentrations .............................................................................2

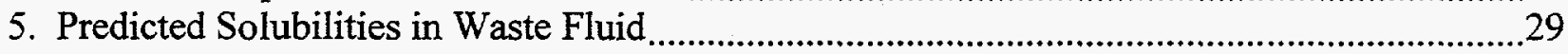

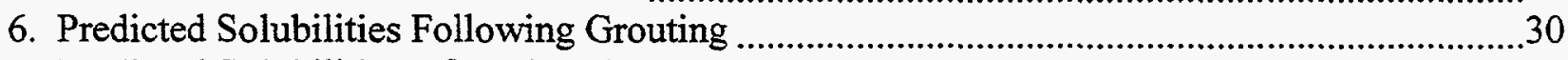

7. Predicted Solubilities After Phosphate Addition ..............................................................22

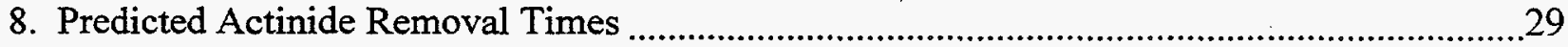




\section{INTRODUCTION}

Five closure strategies have been considered for decommissioned waste tanks and contaminated soils at the Hanford AX tank farm: (1) emplacement of smart cementitous grouts and/or other materials, (2) injection of minerals into contaminated soils surrounding tanks (soil mixing) that will chemically fix specific radionuclides and metals, (3) emplacement of grout barriers under and around the tanks, (4) the explicit recognition that natural attenuation processes do occur, and (5) combined geochemical and hydrologic modeling of soil-grout-waste interactions. Detailed tabulations of stabilization options for tanks and contaminated soils have been recently proposed (e.g., Kincaid et al., 1993; Treat et al., 1995), and a summary of our recommendations in these areas can be found in Sections 2-5 of this report. Solidification and stabilization technology is currently being used to treat a wide variety of wastes, and advancements taking place elsewhere in the cement industry are contributing to continuous integration of new technologies at sites throughout the United States. The engineering-related recommendations presented in this report are therefore posed as general guidelines, and will assuredly require adjustments in light of these changing technologies.

Despite the apparent rapid evolution of solidification and stabilization cement technologies, considerable uncertainty remains regarding radioactive waste stabilization and the chemical processes that occur as the various components of a disposal package interact. In Section 6 we approach this problem through an integrated, site specific study of tank AX-102, considering: (1) the effect of ground water incursion on the estimated waste inventory, (2) cement-waste package effects on actinide solubilities, and (3) the effect of adding specific minerals as chemical getters to the waste backfill. The chemistry of tank AX-102 waste is based on an estimated inventory following retrieval of $90 \%$ of the waste (Ramsower, 1997). Ground water infiltration rates are taken from studies of the local hydrogeology (Fayer and Walters, 1995). Predicted actinide solubilities were performed using the program "React" (Bethke, 1994), which was used to calculate aqueous and surface speciation in an assumed baseline condition and in three assumed closure scenarios involving cement grout and soil backfill materials. The models are accurate only to the degree to which the baseline chemical inventories of Hanford tanks have been estimated. Additional information regarding phase mineralogy and radionuclide 
speciation may be needed to understand more fully the chemical equilibria of initial fluid-mineral system(s) for each tank. However, in the absence of these data we contend that the models in Section 6 are reasonable first-order estimates of the solubilities and retardation factors that can be expected in tank AX-102 under the prescribed conditions.

\section{EMPLACEMENTS WITHIN TANKS}

\subsection{Filler, Design}

A review of the substantial literature on Hanford tank closure options revealed that mechanical stabilization is best achieved by backfilling with an inexpensive coherent filler material. Candidate materials range from crushed and sieved basalt to grouts (Smyth et al., 1992). However, as long as tank integrity is maintained, there is the possibility that water will collect and create a reservoir of fluid in contact with residual waste. Minimization of filler pore space and reduction of pore diameter to the point where capillary forces will hold the fluid in place would minimize fluid-waste contact. In addition, the use of multiple sealant layers above the waste would reduce the possibility that a single crack could form that extended from the top to the bottom of the tank fill.

Tank filling strategies range from emplacement of granular materials to pumping of a semi-fluid material. Granular material emplacement necessitates (1) the regular distribution of material into the tank, and (2) compaction of the material to its "final" density in the time allotted for the closure process (Smyth et al., 1992). The engineering challenges of achieving these two goals are considerable. Rather, we prefer injection of semi-fluid materials that would flow over the irregular surfaces in each tank. Two cementitous grouts are identified with the requisite longevity and low cost; Portland cement-based and bentonite-based. Several commercially available bentonites such as Volclay $®$ and Benseal $@$ may be emplaced as fluids and induced to seal. These are common components of subsurface barriers and the emplacement technologies are well established (Rumer and Mitchell, 1995). Costs are on the order of $\$ 125$ per ton of material. Wakeley and Ernzen (1992) developed a Portland cement-based grout with the appropriate rheological and thermal properties for "mass emplacement." Components of the grout are those typical of most Portland cements so the cost of the materials will be similar to the cost of normal concrete. Because the material is designed to fill vaults, emplacement costs are 
not excessive. This material should serve as a starting point for additional developments in the field (e.g., incorporation of fiber reinforcement that would inhibit crack propagation). A variety of fibrous materials (steel, glass, cellulose etc.) have been evaluated (Kosmatka and Panarese, 1990 ) with the objectives of increasing the resistance to cracking and the overall toughness of cement castings. Additional research should examine novel materials such as graphite fiber, which might have a longer lifetime in the tank environment.

We propose a layered, cementitous grout backfill structure rather than filling the tank with a single massive grout formulation (figure 1). Successful placement of multiple 16 inch layers of grout (dark lines in the blue field in figure 1) under simulated Hanford Grout Vault Program conditions has been demonstrated (Wakeley and Ernzen, 1992). We also recommend a similar lift pouring strategy with sufficient intervening time to allow for the heat liberated in setting to dissipate. A 2 feet thick Benseal $@$ layer about 8 feet from the top of the stack is also recommended to help seal the underlying grout layers and to inhibit the formation of long, through-tank cracks. Consideration was given to placing bentonite layers further down as well, but it is not clear that the bentonite would support a greater thickness of grout, particularly if the tank walls failed and some of the clay was extruded into the surrounding formation.

\subsection{Filler, Function}

The function of this package is hydrologic and is intended to divert water away from the tank and preclude undue wetting of the waste (Kincaid et al., 1993; section 5.2 therein). Cracks through the grout layers as a result of settling, seismic disturbances, etc. would terminate when they encountered the plastic Benseal $\otimes$ or Volclay $\otimes$ layers. Conversely, any contraction of Benseal $\circledast$ or.Volclay $®$ layer would create only a very small zone of porosity before encountering a rigid grout member. The hydraulic conductivity of a "tight" grout or concrete is typically at least three orders of magnitude less than soil, and the pore diameters in grout are also significantly less than that of the poorly sorted gravel fill surrounding the tanks (Brendel, 1997). Once the gravel fill becomes dampened, its hydraulic conductivity will increase (Wierenga, 1995) and it will become the preferred path for draining the top of the tank. Thus, if a sustained flux of water managed to penetrate the Resource Conservation and Recovery Act (RCRA) cap, the gross effect of the design would be to divert the flow around the tank and the waste inside. 


\subsection{Filler, Research}

1. Better definition of the Portland cement and bentonite based grouts to be used.

2. Structural engineering of the tank filling: The design inherently incorporates strong (brittle) and weak (plastic) layers that in aggregate will exert a significant pressure on the bottom

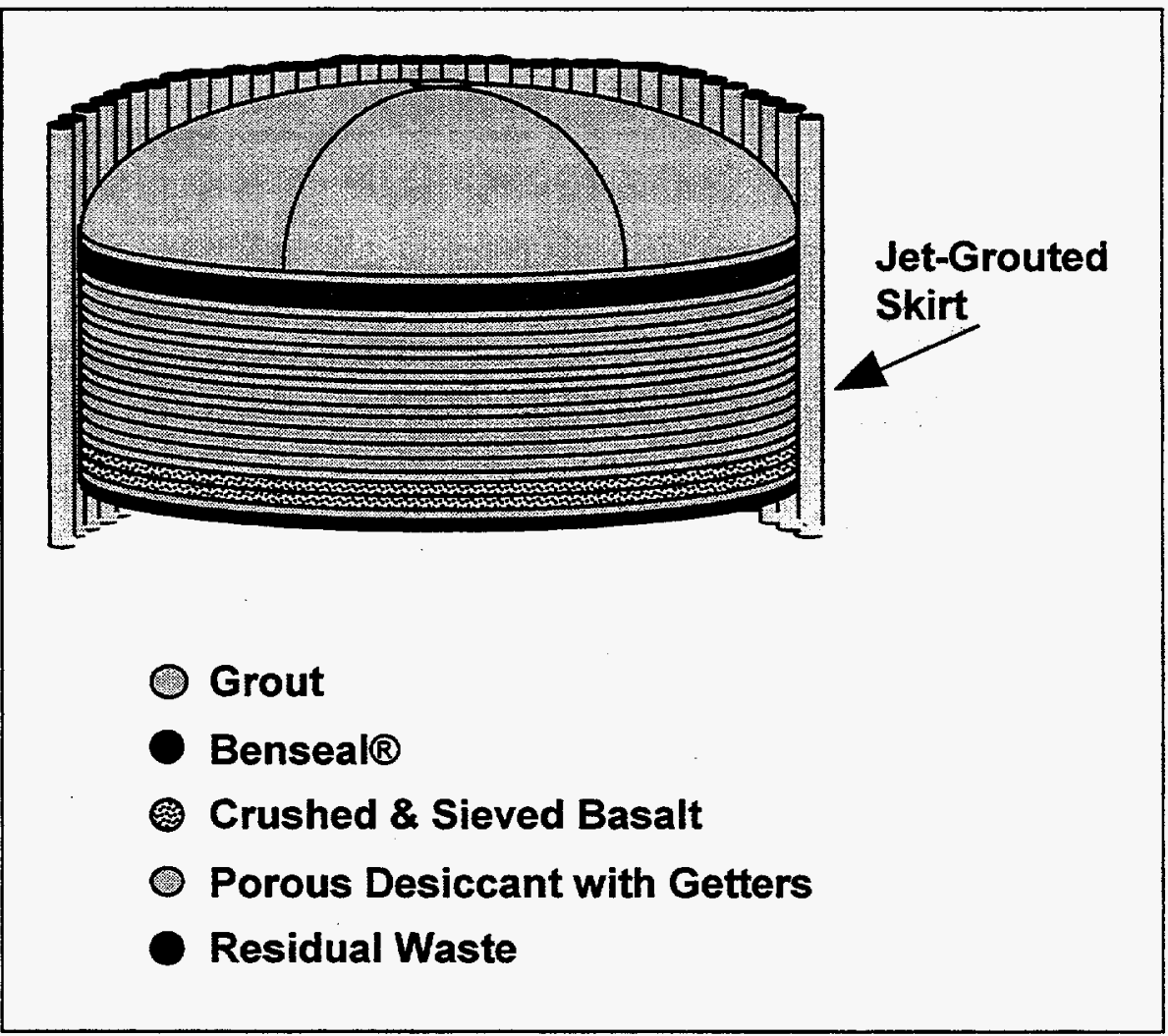

Figure 1. Proposed tank stabilization scheme

and sides of the tank. The design should be one that is inherently stable and able to support its own weight.

3. Chemical stability of the bentonite-Portland cement interface: Bentonite seals are typically emplaced with the clay in the Na-exchanged form because such clays are readily in water. The bentonite seal will, however, be in contact with the Portland cement based materials on both sides. Bentonite clays used in grouts typically are converted to the $\mathrm{CSH}$ and $\mathrm{CAH}$ phases indigenous to Portland cements (Rumer and Mitchell, 1995). Even if conversion does not occur, there will be some displacement of $\mathrm{Na}$ by $\mathrm{Ca}$ on the clay exchange sites, causing an increase in 
clay permeability and a drop in plasticity (Grimm, 1968). For the natural equivalent of a marl, the chemical effect of concrete on pore water chemistry is calculated to extend out about 0.2 meters in 12,500 years (Eikenberg and Lichtner, 1992), which suggests that if an unreacted septum of clay is to exist sandwiched in concrete, the barrier should be on the order of $60 \mathrm{~cm}$ thick. Clearly, the process needs to be quantified (e.g., Lee et al., 1995) for the conditions relevant to the planned structure.

4. Continued evaluation of concrete longevity; apply models to site-specific circumstances and catalogue studies on the longevity of buried concrete structures. We note that the short service life of concrete in many performance assessment documents pertains to the near-surface environment in which freeze-thaw and wet-dry cycles significantly enhance degradation rates. In deeper environments these effects are lessened and we expect to show that significantly longer service lives are appropriate.

\subsection{Waste horizon treatment, design}

The state of the residual waste is also a concern. Current strategies for pre-closure treatment of the tanks call for repeated sluicing to remove in excess of $90 \%$ of the contents and preferably at least $99.9 \%$. A significant fraction of the residuum is expected to be a watery fluid. The remainder will consist of discarded equipment and a pasty to semi-cemented mass of hydrous iron and aluminum hydroxide "sludge" adhering to the interior surfaces of the tank. Radionuclides sorbed on the solid fraction of the sludge will leach with difficulty. However, radionuclides in the sludge pore fluids and the watery fluid overlying the sludge will be highly mobile. The most abundant long-lived radionuclides of concern are: $\mathrm{Tc}, \mathrm{U}, \mathrm{Pu}, \mathrm{Np}$ and $\mathrm{Am}$.

A two-part strategy is proposed for treating the residual waste (figure 1). Initially, dry Portland cement (or other low-cost additives such as fly ash and lime) will be added to desiccate the waste. The next layer consists of crushed and sieved basalt with enough pore space to accommodate any of the pasty sludge that is displaced upward by the weight of the grout/bentonite cap. If only a few inches of sludge exists, the crushed stone can be omitted because the desiccant will likely wick the upper few inches of sludge dry and consume the overlying fluid. In either case, the waste heel will be quite porous so little hydrologic benefit can 
be ascribed to this treatment.

The goal of treating the waste using chemical means is to reduce radionuclide concentrations in solution. This goal can be accomplished with getters added to the waste prior to or during the desiccation step. For optimal getter performance, it may be desirable to neutralize the fluid with an acidic solution or to fill the headspace of the tank with an acidic gas, such as carbon dioxide. The excess carbonate produced by this process would be consumed when the first rise of portland cement was added so this procedure would not create a long lived fluid high in soluble carbonate that would be conducive to mobilizing. The getters we propose would work by either ion exchange or by precipitating a phase containing the radionuclide of concern. A summary of potential getters is presented in Table 1.

Ramsower (1997) derived radionuclide concentrations from mass balance estimates in the retrieval scenarios for the four $\mathrm{AX}$ farm tanks. Tank AX-102 fluids have the highest radionuclide concentrations, whereas concentrations in the remaining three tanks may be four orders of magnitude lower. For conservative estimates we use the concentrations given for Tank $\mathrm{AX}-102$ (Table 2). Also reported are AX-102 supernate analyses for $\mathrm{Am}$ and $\mathrm{Pu}$ of $1.2 \times 10^{-5}$ moles/liter and $0.5 \times 10^{-5}$ moles/liter, respectively (Ramsower, 1997; see Tables 2-4 therein). Dissolved concentrations of Am are in reasonable agreement with Table 2, whereas the Pu value is $\sim 13 \mathrm{x}$ lower. Am is apparently soluble in the tank fluids, but much of the $\mathrm{Pu}$ (and probably $\mathrm{U}$ and $\mathrm{Np}$ ) may be associated with the solids in the sludge.

\subsection{Waste Horizon Treatment, Function}

Although we have not fully evaluated the reactivity of each getter, the literature contains sufficient information to make the following predictions:

1 Magnetite $\left(\mathrm{Fe}_{3} \mathrm{O}_{4}\right)$ has been shown to lower aqueous $\mathrm{Tc}$ concentrations from an initial value of $10^{-6}$ molar to a final value of $10^{-7} \mathrm{molar}$ (Chu and Eriksen, 1996). However, the reaction is very slow in strongly basic solutions, and the solubility of $\mathrm{TcO}_{2}$ increases above a $\mathrm{pH}$ of 9 due to the formation of the $\mathrm{TCO}(\mathrm{OH})^{-}{ }_{3}$ complex. At $\mathrm{pH} \sim 12$, Tc solubility reaches a value of $10^{-4}$ molar (Eriksen et al., 1992). It may be necessary to temporarily neutralize the residual waste to accommodate $\mathrm{Tc}$ removal. Re-release of $\mathrm{Tc}$ is very slow; once it is sequestered by magnetite $\mathrm{Tc}$ should not go back into solution following grout emplacement. 
2. A number of phases exist might sequester the different valences of uranium. The following discussion focuses on the use of cementitous materials to fix the more mobile U(VI) species. U(IV) solubility is exceedingly small. Theoretically, solubilities for U(VI) in a cementitous matrix range from $10^{-4}$ to $10^{-14} \mathrm{M}$ (Berner, 1990), which is in approximate agreement with the calculated solubility of $10^{-15} \mathrm{M}$ determined from equilibrium state model of a grouted sludge pore fluid obtained using the React code (Bethke, 1994). However, in practice the measured value ranges from $10^{-7}$ to $10^{-8}$ molar (Atkins and Glasser, 1990; Moroni and Glasser, 1995), which is significantly lower than the value proposed in Table 2.

Table 1. Potential Getter Materials For Various Radionuclides

\begin{tabular}{|c|c|c|}
\hline Radionuclide & Getter Material & Cost \\
\hline Cs & $\begin{array}{l}\text { Crystalline Silicotitantate Titanate (CST) } \\
\text { Illitic Clays }\end{array}$ & $\begin{array}{l}\text { Expensive } \\
\text { Inexpensive }\end{array}$ \\
\hline $\mathrm{Sr}$ & $\begin{array}{l}\mathrm{CST} \\
\mathrm{SrCO}_{3} \text { - possibly with a } \mathrm{CaCO}_{3} \text { carrier }\end{array}$ & $\begin{array}{l}\text { Expensive } \\
\text { Inexpensive }\end{array}$ \\
\hline $\mathrm{Am}$ & $\begin{array}{l}\text { Hydroxycarbonate - coprecipitated with } \mathrm{Nd} \\
\text { Hydroxyapatite }\end{array}$ & $\begin{array}{l}\text { Inexpensive } \\
\text { Inexpensive }\end{array}$ \\
\hline Tc & $\begin{array}{l}\text { Magnetite or other reducing agent } \\
\text { (may require nearly neutral solution to work quickly) }\end{array}$ & Inexpensive \\
\hline $\mathrm{Np}, \mathrm{Pu}$ & $\begin{array}{l}\text { Hydroxyapatite } \\
\text { Ca-phosphate coprecipitation } \\
\text { FeOOH }\end{array}$ & $\begin{array}{l}\text { Inexpensive } \\
\text { Inexpensive } \\
\text { Inexpensive }\end{array}$ \\
\hline $\mathrm{U}$ & $\begin{array}{l}\text { Magnetite or other reducing agent } \\
\text { Ca-phosphate coprecipitation } \\
\text { Ca-uraninates/cement phases }\end{array}$ & $\begin{array}{l}\text { Inexpensive } \\
\text { Inexpensive } \\
\text { Inexpensive }\end{array}$ \\
\hline $\mathrm{Se}$ & $\begin{array}{l}\mathrm{FeOOH} \\
\text { Fe-Hydrotalcite } \\
\text { (both may require nearly neutral solution to form) }\end{array}$ & $\begin{array}{l}\text { Inexpensive } \\
\text { Inexpensive }\end{array}$ \\
\hline I & $\begin{array}{l}\mathrm{Cu} \text { oxides and sulfides } \\
\mathrm{Ag} \text { compounds }\end{array}$ & $\begin{array}{l}\text { Inexpensive } \\
\text { Inexpensive }\end{array}$ \\
\hline
\end{tabular}

Table 2. Radionuclide Concentrations in Tank AX-102 Rinses 


\begin{tabular}{|c|c|}
\hline Radionuclide & Concentration (mol/L) \\
\hline \hline $\mathrm{Tc}$ & $9 \times 10^{-6}$ \\
$\mathrm{U}$ & $6 \times 10^{-3}$ \\
$\mathrm{Pu}$ & $7 \times 10^{-6}$ \\
$\mathrm{Am}$ & $4 \times 10^{-6}$ \\
$\mathrm{~Np}$ & $3 \times 10^{-6}$ \\
\hline
\end{tabular}

3. Plutonium exhibits a variety of valence states, and like uranium, the tetravalent state is highly insoluble. The fact that $\mathrm{AX}$ tank fluids contain about $10^{-6}$ moles/liter dissolved $\mathrm{Pu}$ indicates that an appreciable fraction exists in the hexavalent state. Therefore Pu behavior should resemble that of uranium, and its solubility should undergo a 10 to 100 fold decrease in a cementitious matrix. This is in part supported by React model calculations for a theoretical waste package (see Section 6 of this report for details), which demonstrate similar $\mathrm{U}$ and $\mathrm{Pu}$ solubilities at $\mathrm{pH}$ 13. The $\mathrm{Kd}$ for $\mathrm{U}$ and $\mathrm{Pu}$ on suitable materials (Table 1) is predeicted to be about $10^{3}$, which is supported by the fact that in saturated $\mathrm{NaCl}$ brines we have measured a value of 980 . In the high $\mathrm{pH}$ tank environment, however, this value may drop but this may be compensated for by the large drop in $\mathrm{U}$ and $\mathrm{Pu}$ solubility in the presence of grout-related fluids.

4. Am presents an interpretation problem. On one hand, the hydroxy-carbonates of trivalent ions are exceedingly insoluble (Felmy et al., 1990; Carroll, 1993). Given the high concentrations of hydroxide and carbonate in these fluids, the solubility of Am should be less than $10^{-7} \mathrm{M}$. Yet, supernate $\mathrm{Am}$ concentrations on the order of $10^{-5} \mathrm{M}$ indicates that there may be other carbonate complexes that have yet to be evaluated. Fortunately, hydroxyapatite appears to have a very high $\mathrm{Kd}$ for $\mathrm{Am}$, in excess of 50,000 in the neutral $\mathrm{pH}$ range. $\mathrm{Kd}$ determinations at high $\mathrm{pH}$ are not available, however for the calculations presented below we conservatively assume an order of magnitude reduction in Kd. Again, issues of capacity exist as does the possibility that some Am complex will exist that is unique to these fluids. 
5. Hydroxyapatite appears to have a very high $\mathrm{Kd}$ (greater than 59,000 ) for $\mathrm{Np}$ under normal $\mathrm{pH}$ conditions. However, like $\mathrm{Am}$, the $\mathrm{Kd}$ for $\mathrm{Np}$ will certainly drop in the higher $\mathrm{pH}$ range, and for this reason we scale the $\mathrm{Np} \mathrm{Kd}$ back 10 times to a value of 5,900. 


\subsection{Waste Horizon Treatment, Research}

1. Explore the systematics of $\mathrm{Tc}$ sorption on magnetite in the relevant solutions. This will be an experimental study where typical simulant tank fluids will be diluted, neutralized to varying degrees with $\mathrm{CO}_{2}$, and then spiked with $\mathrm{Tc}$. Different forms of magnetite and other $\mathrm{Fe}^{+3} / \mathrm{Fe}^{+2}$ solid preparations will also be added. For those getters that successfully remove $\mathrm{Tc}$, the desorption kinetics will be determined at $\mathrm{pH}$ values likely to exist in cement pore fluids (a pH of about 12 to 13$)$.

2. $\mathrm{U}$ and $\mathrm{Nd}$ will be used as surrogates for $\mathrm{Pu}$ and $\mathrm{Am}$ to experimentally evaluate the systematics of sorption on hydroxyapatite in simulant solutions is proposed (see \#1 above). The effectiveness of pre-formed hydroxyapatite in removing these elements will be compared with that of precipitating fresh calcium phosphate in solutions that are pre-spiked with $\mathrm{Nd}(\mathrm{Am})$ and $\mathrm{U}$.

3. Resolve the issue of why the $A m(N d)$ appears to remain in solution when the calculated solubility appears to be so low. This will be a combined computational and experimental study. Two computer codes based on thermodynamic equilibrium are available (React and EQ3/6) and will be applied to the problem.

4. Do a mock-up of the sludge desiccation process with emphasis on characterizing both the chemical and textural features that result, as well as determining the thickness of an artificial sludge heel that can be desiccated.

5. Provide React and EQ3/6 computations to demonstrate that tetravalent $\mathrm{U}$ and $\mathrm{Pu}$ concentrations should remain much less than $10^{-8}$ molar over the relevant range of conditions.

\section{GROUT BARRIERS UNDER AND AROUND THE TANK}

\subsection{Design}

Rumer and Mitchell (1995) edited a definitive work on the construction of subsurface 
barriers. General costs and dimensions that can be achieved with existing technologies are listed in Table 3. Only inorganic materials were considered for this application because organic chemical grouts have not been demonstrated to have lifetimes commensurate with the required regulatory time frame.

Table 3. Representative Costs of Different Types of Barriers

\begin{tabular}{|l|c|c|c|c|}
\hline \multicolumn{1}{|c|}{ Wall Type } & Width $(f t)$ & Depth $(f t)$ & Unit Cost $\left(\$ / f t^{2}\right)$ & $\begin{array}{c}\text { Production Rate } \\
\left(f^{2} / 10 \text { hrs }\right)\end{array}$ \\
\hline \hline Soil Bentonite & $2-3$ & 80 & $2-8$ & $2500-15000$ \\
Cement & $2-3$ & 80 & $5-18$ & $1000-8000$ \\
Bentonite & $2-3$ & 70 & $7-25$ & $1500-5000$ \\
Biopolymer & & & & \\
Drain & 2.5 & 90 & $6-15$ & $1000-8000$ \\
Deep Mixing & 2.5 & 90 & $15-30$ & $1000-3000$ \\
D-mix, Structural & $1.5-3$ & 200 & $30-80$ & $200-2500$ \\
Jet Grouting & $0.5-1$ & 200 & $40-100$ & $200-1000$ \\
Grout Curtain & & &
\end{tabular}

The third part of our design is a skirt to be emplaced against the exterior walls of the tank (figure 1). Because it is desirable to minimize the amount of soil brought to the surface, and because a close bond to the curved outside tank surface is needed, jet grouting is the preferred emplacement technology. The skirt would extend some distance beyond the base of the tank, and would have a wall thickness of about a meter. A 3-feet thick skirt 50 feet high would contain about $1000 \mathrm{~m}^{3}$ of grout and cost about $\$ 24 \mathrm{~K}$ (Dwyer, 1994).

\subsection{Function}

The grouted skirt performs two functions. By extending beyond the base of the tank it diverts the flow of ground water past the base of the tank. Thus, unless a fracture penetrates the tank fill the only remaining mechanism for moving waste downward from the base of a decommissioned tank would be diffusion, which is exceedingly slow when the concentration gradient through unsaturated soil is small and distances of many feet are involved.Secondly a skirt would inhibit the lateral transport of radionuclides outward and the prevent horizontally 
moving ground water from entering a tank.

A minimum tank wall thickness of 1 meter would be needed to guarantee performance of the skirt over the projected 10,000 year survice life. As a limiting case, the concrete might be supposed to degrade because a vital component such as $\mathrm{Ca}$ was being removed by groundwater flowing over the surface, or a deleterious component such as sulfate was diffusing inward. Assuming a diffusion coefficient on the order of $10^{-8} \mathrm{~cm}^{2} / \mathrm{sec}$ (Walton et al., 1990) a reaction front originating from a fixed surface concentration will only propagate about 0.5 meter into the mass in 10,000 years. The same mathematical formalisms also apply the movement of a reaction front (involving radionuclides) from inside the tank outward Thus the same dimensions are also what is needed to argue that the skirt would be a barrier to the escape of radionuclides. Although many refinements on this calculation are possible (e.g., Haworth et al., 1988; Alcorn et al., 1990;

Walton et al., 1990; Lin, 1991; Adenot and Buil, 1992; Buil et al., 1992; Pihlajavaara, 1992) they all rest on the basic assumption of diffusion so it is unlikely that the basic picture would change appreciably with more advanced modeling.

Two points need to be made in regard to this design. First, to fully quantify its function will require a specialized fluid flow model able to handle small scale geometric details. Second, the skirt does not have to be a perfect barrier. A $90 \%$ effective skirt would decrease the source term to the far field performance model by a factor of 10 . This can make a significant difference in the outcome of such a calculation.

\subsection{Research}

1. There is no chemical benefit to this component so the issues associated with its implementation are hydrologic. At least in its simplified form it should be possible to model the flow lines around such a geometry using TOUGH2, written by Karsten Preuss at Lawrence Berkeley Laboratory. Issues such as (1) the optimal extent of the skirt below the tank bottom, (2) the minimum acceptable hydraulic conductivity of the grout and clay layers filling the tank, (3) the impact of increasing rainfall, and (4)the implications of hypothetical hair line cracks (either in the tank filling plug or between the wall of the tank and the skirt) on overall water flow patterns could also be addressed (e.g., Walton et al., 1990).

2. Continue to evaluate new barrier technologies, such as shorter lived organic membranes that might facilitate sealing the tanks during waste removal. 


\section{CHEMICAL INJECTION OF SOILS (SOIL MIXING)}

\subsection{Design}

Directional drilling is required to emplace barriers beneath the tanks. The typical geometry is a V-shaped pattern of holes that intersect beneath the tank (e.g., Treat et al., 1995). Assuming the tank bottom to be at a depth of 55 feet (Kos, 1997) and using a $45^{\circ}$ inclined hole, a 190 foot long hole would be required to penetrate to the center of the AX tank farm "fourplex". The depth of the hole at this point would be 135 feet so this intersection would be above the water table. The entire area of the grout panels (including end caps) is about $1.12 \times 10^{5}$ square feet.

Such a barrier was constructed by jet grouting around a small 7,500 liter tank at the Hanford Geotechnical Facility in Area 400 at a cost of $\$ 24 / \mathrm{m}^{3}$ (Dwyer, 1997). Peterson and Landis (in Rumer and Mitchell, 1995, pp. 185-209) discuss such structures in detail and are less encouraging regarding costs: "Jet Grouting. For conventional civil engineering applications, high pressure jet grouting typically costs $\$ 15$ to $\$ 20$ per square foot for columnar walls. For thin diaphragm walls using jet grouting, costs are estimated at $\$ 10$ to $\$ 15$ per square foot. For estimating purposes, it is assumed that the typical high pressure jet grouted wall has a diameter of roughly 6 feet and the thin diaphragm wall length is 5 feet in both directions. In addition, the cost of directional drilling is estimated at $\$ 8$ to $\$ 25$ per square foot for columnar walls drilled on 6-foot centers and $\$ 5$ to $\$ 15$ per square foot for thin diaphragm walls drilled on 10 -ft centers. The installed cost of a jet grouted columnar floor is estimated at $\$ 23$ to $\$ 45$ per square foot and, for thin diaphragm wall floor, $\$ 15-\$ 30$ per square foot. Not included in these estimates are the costs of the grouting materials, waste disposal, and contingencies." In short, to construct this barrier around the fourplex AX tank farm will cost in excess of a million dollars.

A somewhat simpler application of jet grouting would be to treat the contaminated soils around the tanks. Brendel (1997) estimates that there are $1.63 \times 10^{4}$ cubic yards of material surrounding the $\mathrm{AX}$ tank farm. The heterogeneous distribution of these soils would be difficult to treat with any other mass stabilization process. The jet-grouting process would involve vertical drilling of shallow holes and have an associated cost of approximately $\$ 24 / \mathrm{m}^{3}$; total cost would therefore approximate $\$ 300 \mathrm{~K}$. Parenthetically, finely pulverized getter materials might be 
mixed in with the normal grout components so in addition to stabilizing the soil and diverting the flow of groundwater some chemical immobilization of key radionuclides could also be accomplished.

\subsection{Function}

Typically the V-shaped troughs are intended to completely seal the tank off from its surroundings. With the addition of an organic inner liner, this is a tractable problem - at least for the short term (Williams and Ward, 1997). However, given the 10,000 year regulatory period, it is relevant to ask whether this is a desirable objective. A shift to a damper.climate may cause the lined volume to fill with water, thus inducing prolonged leaching of the waste. A better plan would be to inject getters without a binder, thus, creating a permeable reactive barrier (Shoemaker, et al., in Rumer and Mitchell, 1995, ppp.301-353). As with the skirt, the effectiveness is proportional to the actual coverage. If the permeable reactive barrier were $90 \%$ effective at scavenging radionuclides exiting the tank, the source term would be reduced by a factor of ten. However, given the size and cost of the engineering task and the difficulty of verifying a successful emplacement, the rest of the performance assessment should demonstrate a very clear need for this structure before it is seriously proposed.

\subsection{Research}

1. Getter research similar to that proposed for the in-tank stabilization plan discussed in section 2.6. Additional engineering-related issues concerning emplacement options and optimal grout-getter mixtures will also be addressed. 


\section{THE EXPLICIT RECOGNITION OF NATURAL ATTENUATION}

\subsection{Design}

Natural attenuation is not an engineering issue, but rather a recognition of the natural interactions between waste (solutions, usually) and the soils traversed by the waste. Natural attenuation means dilution, dispersion, (bio)degradation, irreversible sorption, and/or radioactive decay of contaminants in soils and groundwaters. Natural attenuation causes a net reduction of contaminant toxicity and human and ecological risk. Most contaminants in soils and groundwaters are naturally attenuated rapidly, and far faster than they can be removed by engineered remediation schemes.

The problem of barrier design for natural attenuation is partly one of how the performance assessment package is developed and partly one of getting the appropriate data. Most performance assessment packages employ a retardation coefficient (referred to as a Kd) approach to model radionuclide retardation so the first step is to get site specific parameters. Thus one "design" for incorporating natural attenuation is to obtain the best $\mathrm{Kd}$ values available for the soils underlying the AX tank farm. Kincaid et al. (1993) provide a Kd tabulation for $\mathrm{AX}$ tank farm soils, but values given for the actinides other than $U$ seem to be much less than might be expected (e.g., Brady and Kozak, 1995). Thus, one way of designing for natural attenuation will be to improve on the $\mathrm{Kd}$ values to be put into the performance assessment calculations.

However, providing the "correct" site-specific Kd values may not really address the issue of incorporating natural attenuation because ultimately the $\mathrm{Kd}$ approach fails to reflect the fact the full range of chemical processes that occur as radionuclides pass through a column of soil or rock. Inaccuracy of the $\mathrm{Kd}$ approach typically arises from one of two causes: (1) precipitation/dissolution mechanisms may dominate, and these simply have no analogue in the mathematics of the $\mathrm{Kd}$ approach, and (2) where ion exchange is actually the proper mechanism, the desorption step may be so slow that assuming reversible equilibrium greatly overestimates the amount of radionuclides available for leaching. Once the proper data are obtained the next step requires rewriting the performance assessment code to account for this new and more complex chemistry. Reactive transport codes are just now making their appearance and would require a substantial effort to embody into the program. 
A final problem in applying natural attenuation is that of obtaining a proper understanding of the mechanism responsible for the present day contamination. Historically, this problem was approached by assuming surface dispersal or a leaking tank, a traditional $\mathrm{Kd}$ transport moder, and the assumption of normal rainfall. From the literature, we are aware of substantial surface leaks at the AX Tank Farm that were followed by extensive water flushing operations (Ramsower, 1997; see Appendix A, pp. 6). This would lead to a far broader initial dispersal of radionuclides than the historic models would predict, and will require specialized approaches before natural attenuation can be realistically applied.

\subsection{Function}

The function of incorporating natural attenuation clearly lies in providing more realistic estimates of expected radionuclide migration rates.

\subsection{Research}

1. Compile a wider list of Hanford Site Kd values and use geochemical modeling codes such as React to interpret the data. In particular, determine where ion exchange is likely to have operated and where it is more likely that concentrations were solubility-limited. This will indicate areas when one would be justified in using a $\mathrm{Kd}$ approach in modeling the migration of a radionuclide.

2. Obtain AX tank farm sediments and perform batch $\mathrm{Kd}$ and column transport experiments using various diluted and neutralized derivatives of the simulant fluids. Because the unique chemistry of the leaked tank fluids will affect $\mathrm{Kd}$ values in a normal groundwater matrix are not likely to be applicable to making predictions in the immediate proximity of a leaking tank. Thus, rather than performing a literature search these parameters will have to be evaluated experimentally. Again, only a few of the relevant elements can be tested easily but this should give a good idea of how much of an effect this can have.

\section{IN-TANK GEOCHEMICAL AND HYDROLOGIC MODELING}

\subsection{Introduction}


The preceding sections summarize a design framework for tank closure that should be. economically feasible while also minimizing worker exposure. We expand on specific technical issues by considering basic hydrologic and geochemical aspects of the near-field tank environment. Hydrologic calculations provide semiquantiative estimates of the water flux expected to reach the waste given four closure scenarios, and the geochemical calculations address the waste remaining in the tanks and possible chemical retardation that could lower the solubility of various radionuclides, with emphasis on the actinides ( $\mathrm{Tc}$ is problematic at high $\mathrm{pH}$; see Section 2.5). Finally, these results are combined to provide relative waste release estimates into the far field environment.

Four closure scenarios are evaluated. First a baseline condition is evaluated where a tank is filled with soil and the flux of water through the package is assumed equal to that of the flux through the soil column alone. In the second scenario the waste is covered with a dry cementgetter mix and the tank is backfilled with soil; ground water infiltration rates are estimated for a typical Hanford soil type. The third scenario examines the effect of grouting on the waste form, and assumes that through-going cracks develop, and that fluid is transported to the waste at some fixed rate. The fourth scenario assumes an intact low permeability grout filler, so that the only escape pathway for radionuclides is by diffusion out of the tank bottom. This scenario requires no hydrologic calculations other than the observation that it is likely that the soil will eventually approach saturation for several feet outward from the tank bottom. Our analysis of the problem also considers the impact of placing RCRA caps over individual tanks or the entire AX tank farm, effectively reducing the infiltration rate of ground water into the tanks for an indefinite time.

\subsection{Hydrologic Modeling}

The flux of water due to downward infiltration is estimated based on simplifying assumptions. More detailed descriptions of infiltration at the Hanford site are given by Fayer and Walters (1995) and Gee et al. (1996). General discussions on estimating infiltration are presented in Bear (1979) and Bouwer (1994). The conceptualized vadose flow system for the tanks in shown in Figure 2.

\subsection{Infiltration rate}


The downward flow and infiltration rate is estimated using the Green and Ampt Equation:

$$
V_{i}=\frac{K\left(H_{w}+L_{f}+h_{c p}\right)}{L_{f}}
$$

$V_{i}=$ infiltration rate (length/time)

$K=$ hydraulic conductivity of the wetted zone

$H_{w}=$ depth of water on top of the soil

$L_{f}=$ depth of the wetting front

$h_{c p}=$ critical pressure head of soil for wetting

$K=a^{*} K_{\text {sat }}$

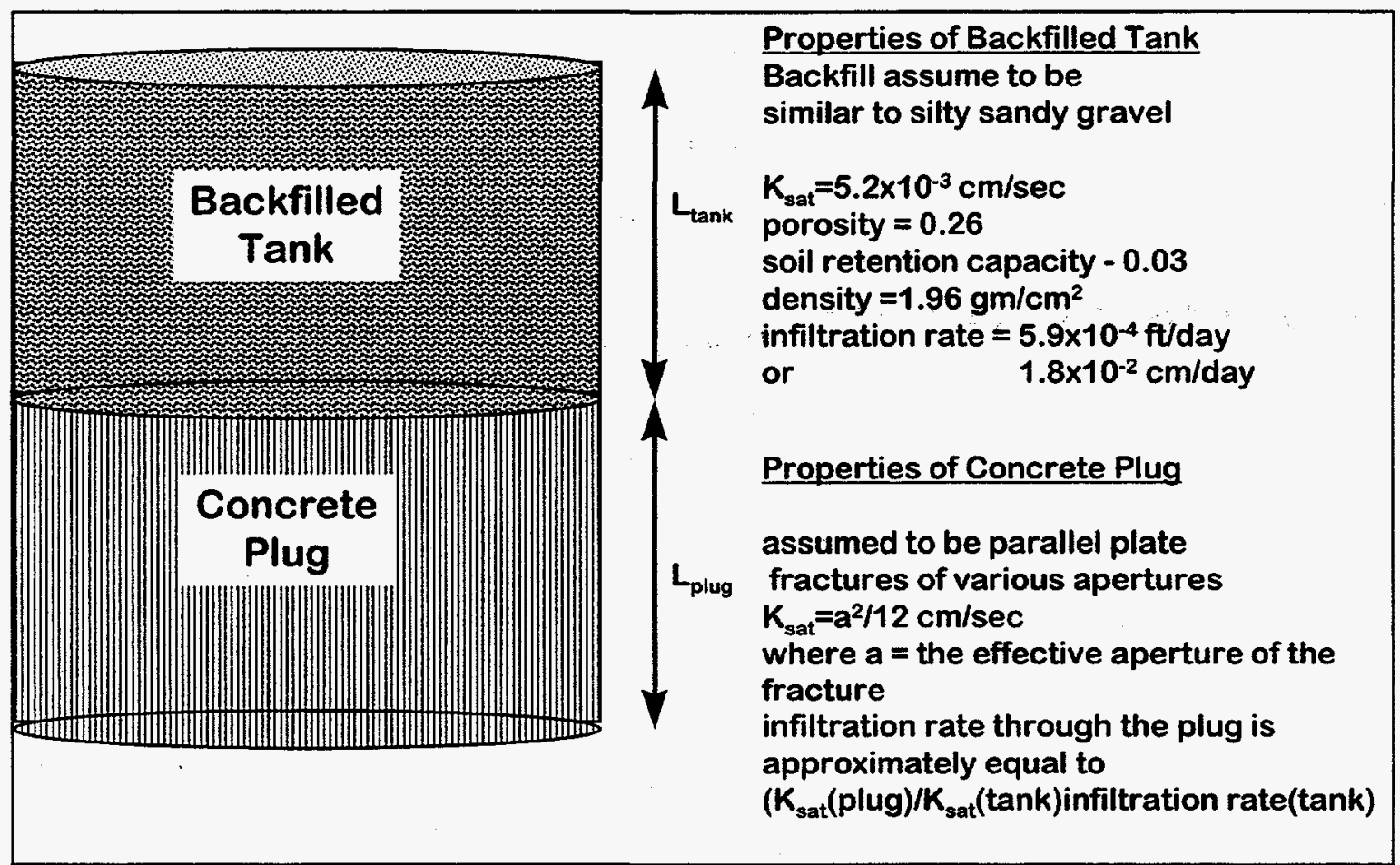

Figure 2. Conceptual Backfilled AX Tank and Underlying Cement Plug with Assumed Hydrologic Properties or Relationships

The Green and Ampt equation can be written for infiltration through the backfilled tank and the underlying cement plug. The infiltration rates for both zones can be ratioed producing the following equations:

$$
V_{i}(\text { plug })=\frac{K_{\text {sat }}(\mathrm{plug})}{K_{\text {sat }}(\operatorname{tank})} * V_{i}(\operatorname{tank})
$$


and for fractured flow (Bear, 1979):

$$
K_{\text {sat }} \text { (plug) }=\frac{a^{2}}{12}
$$

where

$a=$ the effective fracture apertures

values of $K_{\text {sat }}$ (plug) are presented in Table 4 for various apertures

The mean saturated hydraulic conductivity for the silty sandy gravel at Hanford is $8.2 \times 10^{-3} \mathrm{~cm} / \mathrm{sec}$. Based on the ratioed Green and Ampt equation, if the saturated hydraulic conductivity of the plug is greater than $8.2 \times 10^{-3} \mathrm{~cm} / \mathrm{sec}$ (apertures of $0.001 \mathrm{~cm}$ or greater), then the backfilled tank controls the infiltration rate (therefore, the Hanford infiltration rate of $1.8 \times 10^{-2} \mathrm{~cm} /$ day is applicable). If the saturated hydraulic conductivity of the plug is less than $8.2 \times 10^{-3} \mathrm{~cm} / \mathrm{sec}$ (apertures of less than $0.001 \mathrm{~cm}$ ), then the cement plug controls the infiltration rate.

\subsection{Geochemical Modeling}

\subsection{Introduction}

We assume radionuclides remaining in the tank will exist either as solid components in the sludge or dissolved components in the fluid phase. Radionuclides associated with the sludge may either exist as their own phases or as sorbed and coprecipitated components on the nonradioactive materials that make up the bulk of the solids (principally iron and aluminum hydroxides). Weakly sorbed highly soluble components such as technetium and cesium will reside almost entirely in the aqueous phase; for others, such as $\mathrm{Sr}$ and $\mathrm{Am}$, the opposite is true. However, for the actinides, the distribution is less certain and may depend on their ionic speciation in the tank fluid, which, in turn, may change with time. Thus, a major objective is to obtain basic solubility information on the actinides in order to assess probable distributions among the various phases.

The second objective is to evaluate getter performance; the study of sorption and desorption processes in this unique chemical environment is in its initial stages. In Section 2.4 we recommend several getters (Table 1) in addition to endorsing the use of grout to fill the tanks. In the following discussions we quantitatively evaluate simple grout-waste interactions and 
examine the effect of adding phosphate to precipitate an insoluble actinide phosphate.

\subsubsection{Approach}

The React code (Bethke, 1994) was used to calculate actinide solubilities. The code uses a thermodynamic approach to calculate the equilibrium configuration of various fluid-solid assemblages based on their bulk chemistry. In setting up the problem it was assumed that tank closure would result in recovering about $90 \%$ of the waste. Although the Tri-Party Agreement mandates that $99 \%$ of the waste be retrieved, we used a $90 \%$ retrieval target as a worst-case scenario. In effect, this results in a 10-fold dilution of the waste fluid. Residual radionuclides concentrations are listed in Table 2, and the resulting trial fluid composition (after the 10-fold dilution) is given in Table 4. The database used in React contains all of the common components of the tank fluids, with the exception of oxalate. Oxalate values were added to the database (Pearson et al., 1992) because oxalate is known to be a powerful actinide complexing agent. Speciation diagrams for $\mathrm{U}(\mathrm{VI}), \mathrm{Pu}(\mathrm{VI}), \mathrm{Np}(\mathrm{V})$ and $\mathrm{Am}(\mathrm{III})$ were generated using the React code and modified database (see Appendix A), and four scenarios were tested for each actinide whereby carbonate and phosphate were variably added to the fluid (see discussion below for a detailed explanation). In addition to the normal chemical designations the various figures contain the abbreviation "ox," designating the presence of oxalate. These calculations and accompanying figures are based on our current best-estimates of tank fluid chemistry and groutgetter-fluid interactions. Many of these calculations may require modification as experimental data accumulates.

\subsubsection{Baseline Solubility Calculations}

This set of calculations was performed by conceptually adding 10 grams of each actinide hydroxide to one liter of fluid (Table 5). The $\mathrm{pH}$ was adjusted to span a range from $\mathrm{pH} 6$ to $\mathrm{pH}$ 13. For both $\mathrm{Pu}$ and $\mathrm{U}$ valences a general decrease in concentration occurs as the $\mathrm{pH}$ rises. Oxalate complexes are only important in the $\mathrm{pH} 6-8$ range, and above $\mathrm{pH} 8$ the carbonate complexes account for most of the dissolved concentrations. Neptunium solubilities are universally high due to carbonate complexing above $\mathrm{pH} 9$ and formation of oxalate complexes below $\mathrm{pH} 9$.

Comparisons with Table 2 indicate that $U$ in the tank fluids is in excess of the saturation 
limit, however if the $\mathrm{pH}$ were slightly lower than $13, \mathrm{U}(\mathrm{VI})$ might well be in equilibrium with the fluid, though the solubility curve is so steep in this situation that it is difficult to arrive at more than a tentative conclusion. The tank fluids (and thus the concentration of the complexing carbonate) were hypothetically diluted by a factor of 10 for this calculation, dropping the radionuclide concentration ranges from $\sim 10^{-6}$ to $\sim 10^{-7} \mathrm{M}$. At these concentrations it appears that both $\mathrm{Pu}$ and $\mathrm{Am}$ may be in approximate equilibrium with a solid phase in the tank, whereas $\mathrm{Np}$ is so undersaturated that a solubility limit is unlikely to effect the mobility for this radionuclide. 
Table 4. Trial Fluid Species and Concentrations

\begin{tabular}{|c|c|}
\hline Species & Concentration $(M)$ \\
\hline \hline $\mathrm{NO}_{3}{ }^{-}$ & $0.51^{*}$ \\
$\mathrm{Al}^{3+}$ & 0.006 \\
$\mathrm{Na}^{+}$ & $0.73^{\#}$ \\
$\mathrm{SiO}_{2}(\mathrm{aq})$ & $9 \times 10^{-6}$ \\
$\mathrm{Oxalate}^{-6}$ & 0.042 \\
$\mathrm{HCO}_{3} / \mathrm{CO}_{3}{ }^{2-}$ & 0.10 \\
\hline
\end{tabular}

${ }^{*}$ Incorporates $\mathrm{NO}_{3}{ }^{-}$and $\mathrm{NO}_{2}{ }^{-}$

\#Adjusted slightly for charge balance

Table 5. Predicted Solubilities in Waste Fluid

\begin{tabular}{|c|c|c|c|}
\hline Species & pH 6 & pH 11 & pH 13 \\
\hline \hline $\mathrm{Pu}(\mathrm{VI})$ & -2.4 & -6.2 & -8.0 \\
$\mathrm{Pu}(\mathrm{IV})$ & -2.4 & -6.2 & -8.0 \\
$\mathrm{U}(\mathrm{VI})$ & -1.8 & -2.0 & -7.5 \\
$\mathrm{U}(\mathrm{IV})$ & -7.1 & -7.1 & -7.1 \\
$\mathrm{~Np}(\mathrm{~V})$ & 0.0 & -2.0 & -3.0 \\
$\mathrm{Am}(\mathrm{III})$ & -2.0 & -7.4 & -8.4 \\
\hline
\end{tabular}

Values reported as $\log _{10}$.

\subsubsection{Consequences of Grouting}

Grouting the waste has many chemical and mechanical benefits. Grouting will greatly decrease the availability of carbonate in the fluids because calcite $\left(\mathrm{CaCO}_{3}\right)$ will precipitate when portlandite $\left(\mathrm{Ca}(\mathrm{OH})_{2}\right)$ in the grout mixes with carbenate in the waste. Grouting will also lower free phosphate due to the precipitation of hydrous calcium phosphates. To model this process identical simulations were run in the absence of carbonate (Table 6). Note first that many of the pH 6 solubilities did not change significantly because oxalate complexes predominate in this range. However, because Ca oxalate is a relatively insoluble compound $\left(7 \times 10^{-5}\right.$ moles per liter), 
addition of $\mathrm{Ca}$ would remove oxalate and diminish the complexation of radionuclides. The effect of carbonate addition to the predicted concentration of actinide species is shown graphically in Appendix A. For the moment, however, an approximate estimate of the importance of removing oxalate can be obtained by noting that the most abundant complex does not include oxalate.

\subsubsection{Consequences of Phosphate Addition}

Unfortunately, for $\mathrm{Np}, \mathrm{Pu}$, and $\mathrm{U}$, phosphate is better at forming aqueous complexes than at precipitating low solubility phases, particularly near $\mathrm{pH} 13$ (Table 7; the models were run with a fluid containing $0.1 \mathrm{M}$ phosphate). Fortunately, the equilibrium of portlandite, hydroxyapatite and calcite leave negligible concentrations of both carbonate and phosphate in the dissolved phase and therefore not precluding the use of hydroxyapatite getters.

\subsubsection{Summary}

Modeling suggests that significant solubility decreases for the actinides can be achieved by grouting the wastes. However, adding soluble phosphate to precipitate insoluble actinide phosphates provides no added benefit.

\subsection{Getter Addition}

\subsubsection{Hydroxyapatite}

The prospects for using hydroxyapatite as a getter are more encouraging. Experiments were performed for the Waste Isolation Pilot Project (WIPP) in which 2 grams of hydroxyapatite

Table 6. Predicted Solubilities Following Grouting

\begin{tabular}{|c|c|c|c|}
\hline Species & $p H 6$ & $p H 11$ & $p H 13$ \\
\hline \hline $\mathrm{Pu}(\mathrm{VI})$ & $-2.4(-7)$ & -8.8 & -11.6 \\
$\mathrm{Pu}(\mathrm{IV})$ & $-2.4(-5.5)$ & -7.2 & -9.2 \\
$\mathrm{U}(\mathrm{VI})$ & $-1.8(-2.1)$ & -13.5 & -17 \\
$\mathrm{U}(\mathrm{IV})$ & $-7.1(-11)$ & -7.1 & -7.1 \\
$\mathrm{~Np}(\mathrm{~V})$ & $0.0(-4.0)$ & $-5.0(-7)$ & -7.0 \\
$\mathrm{Am}(\mathrm{III})$ & $-2.0(-2)$ & -8.4 & -8.4 \\
\hline
\end{tabular}

Values reported as $\log _{10}$. () approximate value in the 
absence of oxalate, only shown for large differences.

Table 7. Predicted Solubilities After Phosphate Addition

\begin{tabular}{|c|c|c|c|}
\hline Species & $p H 6$ & $p H 11$ & $p H 13$ \\
\hline \hline $\mathrm{Pu}(\mathrm{VI})$ & -1.7 & -8.5 & -10.8 \\
$\mathrm{Pu}(\mathrm{IV})$ & -1.7 & -7.5 & -9.4 \\
$\mathrm{U}(\mathrm{VI})$ & $-1 . .5$ & -1.4 & -1.5 \\
$\mathrm{U}(\mathrm{IV})$ & -1.3 & -2.7 & -2.7 \\
$\mathrm{~Np}(\mathrm{~V})$ & $-1.8(-4)$ & -3.5 & -7.0 \\
$\mathrm{Am}(\mathrm{III})$ & -1.8 & -8.5 & -8.4 \\
\hline
\end{tabular}

Values reported as $\log _{10}$. () approximate value in the absence of oxalate, only shown for large differences.

was added to $250 \mathrm{ml}$ of brine containing $1.7 \times 10^{-7} \mathrm{M} \mathrm{Am}$ and $1.1 \times 10^{-7} \mathrm{M} \mathrm{Pu}$.

Significantly, the actinide concentrations in these studies were about a factor of 10 below that in the actual waste. Thus, to achieve a similar decontamination factor in tank wastes requires $20 \mathrm{~g}$ of hydroxyapatite per $250 \mathrm{ml}$ of tank fluid, which is not a prohibitive quantity.

Significant differences in the degree of complexing in WIPP brines as compared to the tank fluids may exist. We argue, however, that the oxalate, phosphate and carbonate already present in the tank fluids will be tied up in solid phases when grout is added. In this situation the brine will principally be a $\mathrm{NaNO}_{3}$ fluid.

A final consideration is the $\mathrm{pH}$ difference between the WIPP brine and AX tank pore fluids. The $\mathrm{Kd}$ for Pu decreases by roughly a factor of 3 for each increase of two $\mathrm{pH}$ units. Thus, between a pH of 9 and 13 the $\mathrm{Kd}$ should fall by about a factor of 10 . Hydroxyapatite could decrease the dissolved concentrations of $\mathrm{Pu}$ by a factor of 100 compared to the situation where the waste was grouted and no getters were added. The dependence of $\mathrm{Kd}$ for $\mathrm{Am}$ on $\mathrm{pH}$ is more complex. In short term experiments (minutes to hours) the $\mathrm{Kd}$ reaches a maximum value at about $\mathrm{pH} 7$ and then falls by about a factor of 10 at $\mathrm{pH} 9$. With exposures of a day or more, however, the $\mathrm{Kd}$ at $\mathrm{pH}$ values near 9 rebounds to a value that exceeds the short term $\mathrm{pH}$ maximum near $\mathrm{pH}$. This same block of tests failed to find significant $\mathrm{U}$ sorption on hydroxyapatite, probably because carbonate complexes had formed. Thus, it is likely that hydroxyapatite will not be a good getter for uranium. From the preliminary data we observed 
that $\mathrm{Np}$ is sorbed about 10 times better than $\mathrm{Pu}$. Finally, allowing both the $\mathrm{Pu}$ and $\mathrm{Np}$ to equilibrate for several days resulted in significantly higher $\mathrm{Kd}$ values. Thus, the values stated here are probably conservative estimates. 


\subsubsection{Magnetite, etc.}

Presently, the best way of reducing $\mathrm{Tc}$ concentrations in solution is to reduce the $\mathrm{TcO}_{4}{ }^{-}$to the relatively insoluble $\mathrm{TcO}_{2} \cdot \mathrm{nH}_{2} \mathrm{O}$. This process has been reported on in considerable detail with the following results:

a. Ferrous salts in solution generally do a poor job at removing pertechnetate from solution. A solid reducing agent is needed to simultaneously supply all three electrons required for the process (Chu et al., 1996).

b. Magnetite works well only in reducing environments, and its performance is further enhanced if the solution also contains some ferrous iron that can sorb onto the mineral surface synchronously with pertechnetate. Vandergraaf et al. (1984) reported $>95 \%$ Tc removal from a mix of $10^{-4} \mathrm{M} \mathrm{Tc}, 1 \mathrm{~g}$ of magnetite and $10 \mathrm{~g}$ of synthetic ground water under reducing conditions. With $1 \mathrm{~g}$ of powdered magnetite in $7 \mathrm{ml}$ of fluid, the addition of $6 \mathrm{ppm} \mathrm{Fe}^{+2}$ results in more than $95 \%$ removal of the Tc in 48 hours. The $\mathrm{pH}$ was about 8 for these tests and the initial Tc concentration was $10^{-6} \mathrm{M}$. In the absence of $\mathrm{Fe}^{+2}$ only $16 \%$ was removed (Byegard et al., 1992).

c. The rate of $\mathrm{TcO}_{4}$-uptake onto magnetite falls off markedly as the $\mathrm{pH}$ increases, and appears to all but stop above a $\mathrm{pH}$ of 9.5 (Chu and Eriksen, 1996).

d. Metallic iron works effectively even in contact with atmospheric oxygen (Bostik et al., 1990).

e. Metallic iron is not stable over "geologic" time in subsurface environments but magnetite is.

f. Tc(IV) forms a number of aqueous complexes which, in theory, can elevate the solubility significantly. In carbonate-free systems above $\mathrm{pH} \sim 10$, formation of $\mathrm{TcO}(\mathrm{OH})_{3}{ }^{-}$enhances $\mathrm{TcO}_{2} \cdot \mathrm{nH}_{2} \mathrm{O}$ solubility. Below this value the dissolved $\mathrm{Tc}$ concentration is about $10^{-8.2} \mathrm{M}$. At $\mathrm{pH}$ values of 12 and 13 this complex increases Tc solubility to $10^{-7}$ and $10^{-6} \mathrm{M}$ respectively. $\mathrm{Tc}$ (IV) - carbonate complexes also form. $\mathrm{Tc}(\mathrm{OH})_{2} \mathrm{CO}_{3}$ (aq) predominates below $\mathrm{pH}$ of 8 , while above this, $\mathrm{Tc}(\mathrm{OH})_{3} \mathrm{CO}_{3}{ }^{-}$dominates. In carbonate-rich environments both complexes can significantly increase total dissolved Tc concentrations (Eriksen et al., 1992)

g. Once Tc is immobilized by reduction, its release from a grouted waste form with an inherently reducing matrix is exceedingly slow. (Bostik et al., 1988; Tallent et al., 1988; Brodda and Mingxia, 1989).

h. $100 \mathrm{ppm}$ dissolved phosphate also interferes with the sorption of $\mathrm{Tc}$ on magnetite. 
(Vandergaaf et al., 1984)

To summarize, magnetite (and by proxy metallic iron metal) is well documented to have significant capacity for reducing Tc. The best current estimate of the lowest solubility obtainable by reducing pertechnetate is between $10^{-7}$ and $10^{-8} \mathrm{M}$.. Judging from the scant data on removal capacity of magnetite/iron getters if they were added in the amount of $10 \%$ of the waste volume, virtually all of the Tc could be scavenged from solution. This is a feasible concept because neither the cost of the material nor the amount to be emplaced are large. However, it would be prudent to add both metallic iron, for speed, and magnetite, for longevity.

There are two potential problems with this concept. The first is that grout pore fluids have a $\mathrm{pH}$ in the range 12 to 13 . In this environment formation of $\mathrm{TcO}(\mathrm{OH})_{3}{ }^{-}$is possible. Formation of carbonate and phosphate complexes in a grouted waste form should not be problematic for reasons outlined previously. Thus, the solubility of $\mathrm{TcO}_{2} \cdot \mathrm{nH}_{2} \mathrm{O}$ in a cement pore fluid could be almost the same as it was in the diluted waste fluid prior to reduction. A second concern regards the time period over which the waste will remain reducing enough to sequester $\mathrm{Tc}$ in the tetravalent form. A quantitative model for oxygen entry into a grouted waste was proposed by Smith and Walton (1993). This will eventually be applied to our site-specific circumstances to assess whether reducing conditions could persist long enough to significantly reduce $T c$ releases from a decommissioned tank. The current literature does not resolve whether this is a realistic possibility, and therefore Tc is omitted from the following models.

\subsubsection{Summary}

For the $\mathrm{Pu}, \mathrm{Am}$, and $\mathrm{Np}$ addition of a hydroxyapatite getter appears most promising and should lower the solubilities by about a factor of 100 below that expected from just the grouting. For Tc additional work needs to be done before the issue can be resolved. However, it is likely that addition of magnetite plus iron metal can result in solubilities between $10^{-7}$ to $10^{-8} \mathrm{M}$.

\subsection{Radionuclide Release Models}

From the preceding discussion we now provide a relative measure of radionuclide releases for various tank closure scenarios. From a knowledge of the tank inventory, radionuclide solubilities, retardation factors in the presence of added getters, and water flux, it is possible to predict first-order radionuclide release rates and the time required to completely remove specific radionuclides from a tank. For simplicity we assume fluid accumulation at the 
base of a tank to be zero. Future models will undoubtedly accommodate more complex hydrologic parameters. Ultimately, the release rates may serve as inputs for traditional performance assessment packages that evaluate the transport and impact of radionuclide releases into the far field.

The residual wastes in the tank following $90 \%$ retrieval are predicted to be $26.5 \mathrm{~m}^{3}$ sludge and $75.4 \mathrm{~m}^{3}$ saltcake (Ramsower, 1997). No estimates of fluid porosity are provided, however for simplicity we assume the sludge contains $50 \%$ pore fluid and we ignore any fluid contribution from the saltcake layer. Better pore fluid estimates may eventually be available once leach tests are conducted; a $99 \%$ waste retrieval is predicted to remove $100 \%$ of the saltcake layer is predicted to be removed (Ramsower, 1997). Table 8 summarizes the calculations described in detail.

In the baseline scenario, no chemical getters are applied and the tank fill material consists entirely of a typical Hanford soil (Fayer and Walters, 1995). We bound the ground water infiltration effects by using the cases of (1) no cover but native soil backfill and (2) a RCRA cover and a native soil and/or cementitous backfill. Backfill hydrologic properties can be measured, but the RCRA cover properties are design-specific assumptions. These assumptions are made only to limit the range of hydrologic properties. Hanford, INEEL and SRS, for example, have proposed designs for 1000 year covers, hence we do not assess the impact of covers for periods in excess of this duration.

In the absence of a RCRA cover, and at an infiltration rate of $1.8 \times 10^{-2} \mathrm{~cm} /$ day (Fayer and Walters, 1995), approximately 27,000 liters of ground water could enter a tank annually. This is sufficient to fill a tank to a depth of $\sim 7 \mathrm{~cm}$ per year. In the presence of a RCRAequivalent barrier, ground water infiltration is reduced to $9.5 \times 10^{-6} \mathrm{~cm} /$ day (Fayer and Walters, 1995), which is sufficient to fill a tank to a depth of $3.5 \times 10^{-2} \mathrm{~cm}$ per year. The time required to completely displace the pore fluid in the residual sludge is approximately 179 days in the absence of a RCRA-equivalent barrier. The placement of the RCRA-equivalent barrier increases the displacement period to approximately 931 years.

For the second scenario a layer of wicking material (fly ash, dry grout, etc.) containing getters is placed onto the waste and backfilled with soil. Here, mineral Kd's define the retardation times for each radionuclide (Appendix B). The addition of hydroxyapatite to the 
getter inventory will effectively retard neptunium and americium. Kd's on the order of 5-6 x $10^{3}$ for $\mathrm{Np}$ and $\mathrm{Am}$ ( $\mathrm{pH}$ corrected) will increase the time required for complete removal to between 19,000 and 21,000 years in the absence of a RCRA-equivalent barrier. Because of these long Table 8. Predicted Actinide Removal Times

\begin{tabular}{|c|c|c|c|c|c|c|c|}
\hline & \multicolumn{2}{|c|}{ Treatment } & & \multicolumn{2}{c|}{ Moles in Solution } & \multicolumn{2}{c|}{ Removal Time (y) } \\
\hline Scenario & Backfill & Getters & Radionuclide & Initial & After Treating & No Cap & Cap \\
\hline I & soil & none & $\mathrm{U}, \mathrm{Pu}, \mathrm{Np}, \mathrm{Am}$ & Table 2 & $\mathrm{NA}$ & 0.49 & 931 \\
\hline II & soil & added & $\mathrm{U}$ & $8 \times 10^{-1}$ & see & $3.7 \times 10^{2}$ & see text \\
& soil & added & $\mathrm{Pu}$ & $9 \times 10^{-2}$ & Appendix & $3.7 \times 10^{3}$ & for \\
& soil & added & $\mathrm{Np}$ & $4 \times 10^{-2}$ & $\mathrm{~B}$ & $2.2 \times 10^{4}$ & explan- \\
& soil & added & $\mathrm{Am}$ & $5 \times 10^{-5}$ & for Kd's & $1.9 \times 10^{4}$ & ation \\
\hline III $^{2}$ & grout & none & $\mathrm{U}$ & $8 \times 10^{-1}$ & $1 \times 10^{-13}$ & 0.49 & 931 \\
& grout & none & $\mathrm{Pu}$ & $9 \times 10^{-2}$ & $3 \times 10^{-8}$ & 0.49 & 931 \\
& grout & none & $\mathrm{Np}$ & $4 \times 10^{-2}$ & $1 \times 10^{-3}$ & 0.49 & 931 \\
& grout & none & $\mathrm{Am}$ & $5 \times 10^{-5}$ & $5 \times 10^{-5}$ & 0.49 & 931 \\
\hline $\mathrm{IV}^{3}$ & grout & none & $\mathrm{U}, \mathrm{Pu}, \mathrm{Np}, \mathrm{Am}$ & Table 2 & Table 6 & $10^{5}-10^{7}$ & $10^{5}-10^{7}$ \\
\hline
\end{tabular}

NA: Not applicable.

${ }^{1}$ Assumes $13,300 \mathrm{~L}$ fluid in sludge and fluid $\mathrm{pH}$ of 13.

${ }^{2}$ Assumes cracked grout. Infiltration rate equals that of soil backfill.

${ }^{3}$ Non-fractured grout. Assumes diffusion-controlled mechanism. Estimated removal times based on initial flux only.

durations an assessment with RCRA barriers was not performed. Uranium and plutonium have lower Kd's (100 and 1000, respectively) and therefore should flush out earlier. The time required for complete removal is estimated to be about 400 years for uranium and 4,000 years for plutonium in the absence of a RCRA-equivalent barrier. Again, assessments were not made for situations with RCRA barriers.

The third scenario examines the influence of a tank filled with cracked grout, where the grout effectively lowers the solubility of some radionuclides according to the React calculations. With a grid of cracks spaced at $1 \mathrm{~m}$ intervals and with apertures of $0.001 \mathrm{~cm}$ or greater, it was found that the grouted plug would transfer a volume of fluid equivalent to that of the soil column (see Section 6.2). However, the storage capacity of the tank (prior to having incurred a leak) would be much diminished, and, by virtue of the chemical environment imposed by the grout, the solubility of the radionuclides would be diminished from the values in Table 5 (diluted by 10) to 
those in Table 6. In this scenario, although sorption is not the primary retardation mechanism, once a particular radionuclide is precipitated it is effectively isolated from the fluids. Americium solubility is unaffected by grouting, and will therefore remain in the fluid phase in the absence of getters. It should be flushed out of the waste in the time periods calculated in the first scenario. Uranium(VI) displays a sizable solubility drop by a factor of $\sim 3 \times 10^{6} \mathrm{M}$ following its interaction with grout. It , therefore becomes chemically fixed in the presence of grout-related fluids and high $\mathrm{pH}$. A large drop in $\mathrm{pH}$ would dramatically increase U(VI) solubility, however the presence of a large cementitous mass should effectively buffer the $\mathrm{pH}$. The solubility of neptunium and plutonium are calculated to be decreases by a factor of between $10^{3}$ to $10^{4} \mathrm{M}$ in the presence of grout. Addition of getters (specifically hydroxyapatite) wouldl reduce the solubility of $\mathrm{Np}, \mathrm{Pu}$ and $\mathrm{Am}$ by an additional factor of 100 .

In this scenario, it is also relevant to question whether the leaching of radionuclides from the grouted waste would impose a significant barrier. Leaching would involve diffusion from within the grouted mass to the fluid channels. The penetration depth for the leach front is approximated by:

$$
x(\mathrm{~cm})=2(D T)^{\frac{1}{2}}
$$

With a diffusion coefficient of $10^{-8} \mathrm{~cm}^{2} / \mathrm{sec}$, about $1 \mathrm{~cm}$ of penetration is expected in the first year, and $10 \mathrm{~cm}$ after 100 years. It unlikely that grouting the waste will produce a single solid mass of concrete. Thus, the sizes of the individual pieces in the grouted waste will probably not be more than 10 to $20 \mathrm{~cm}$. Thus, on the time scale of relevance, leach rates will not provide a significant barrier to radionuclide releases. To summarize, in this scenario the flux of water is not decreased but actinide solubilities are considerably diminished.

The fourth scenario examines a tank containing an intact plug of low-permeability grout. As crack apertures fall below $10^{-3} \mathrm{~cm}$, the flux of water down through the grouted top of the tank approaches zero and diffusion out of the tank bottom becomes the dominant release mechanism. If the cementitous skirt extends a meter beyond the bottom of the tank then this defines the path length, $\mathrm{L}$. The release rate then is defined by the equation:

$$
\text { Flux }\left(\frac{\text { moles }}{c m^{2} s}\right)=D \frac{C_{1}-C_{2}}{L}
$$


where again $\mathrm{D}$ is less than $10^{-8} \mathrm{~cm}^{2} / \mathrm{sec}$ and the concentration at the bottom of the skirt is assumed to be almost zero. $C_{1}$, the radionuclide concentration in the tank, is fixed by the in-tank chemistry (grout \pm getters). This scenario represents the slowest release mechanism. Assuming the largest concentration gradient (where $\mathrm{C}_{2}=0$ ), calculated fluxes are exceptionally low, ranging from $10^{-20}$ to $10^{-30} \mathrm{~mol} / \mathrm{cm}^{2}$ s for the initial fluxes (Appendix B). These fluxes represent maximum values because flux as a function of time will vary according to reservoir concentration (which will continuously be falling) and the diffusion coefficient, which likely will vary over time. The calculations required to determine times required for complete removal of radionuclides in simple diffusion settings are underway, however we estimate these times will be on the order of $10^{5}$ to $10^{7} \mathrm{y}$.

\section{CONCLUSIONS}

Even in the highly simplified context of the models derived for this report it is evident that a wide range of near field source terms can be justified. Each of these scenarios involves differences in cost and worker exposure. However, by applying these different release models as input to a standard performance assessment package it should be possible to determine what level of expenditure is technically justified in decommissioning each tank. 


\section{REFERENCES}

Adenot, F. and Buil, M., 1992. Modeling of the corrosion of cement paste by deionized water. Cement Concrete Res. 22, 489-496.

Alcorn, S.R., Coons, W.E. and Garniner, M.A., 1990. Estimation of longevity of Portland cement grout using chemical modeling techniques. Mat. Res. Soc. Sympp. Proc. 176, 165173.

Atkins, M. and Glasser, F.PP., 1990. Encapsulation of radioiodine in cementitous waste forms. Mat. Res. Soc. Sympp. Proc. 176, 15-21.

Bear, J. 1979, hydraulics of groundwater, McGraw Hill, New York, 569p

Bouwer, H, 1994, Estimating the Ability of the Vadose Zone to Transmit Liquids, in Wilson, L. G., and others, editors, Handbook of Vadose Zone Characterization and Monitoring, Lewis Publishers, Boca Raton, 177-201.

Bethke, C.M., 1994. The Geochemist's Workbench. A Users Guide to Rxn, Act2, Tact, React, and Gtplot. Univ. of Illinois, Champagne, IL.

Berner, U., 1990. A thermodynamic description of the evolution of pore water chemistry and uranium speciation during degradation of cement, Paul Scherer Institut.

Borns, D.J., 1997, Predictive tools and data needs for long term performance of in-situ stabilization and containment systems. International Containment Technology Conference and Exposition, St. Petersburg, FL, Feb. 10, 1997.

Bostik, W.D., Schoemaker, J.L., Osborne, PP.E., and Evans-Brown, B., 1990, Treatment and Disposal Options for a Heavy Metals Waste Containing Soluble Technetium-99, Emerging Technologies in Hazardous Waste Management, Tedder, D.W. and Pholand, F.G., eds., American Chemical Society, May 1-4, 1989, Atlanta Ga.

Bostik, W.D., Schoemaker, J.L., Fellows, R.L., Spence, R.D., Gilliam, T.M., McDaniel, E.W., Evans-Brown, 1988. Blast Furnace Slat-Cement Blends for the Immobilization of Technetium-Containing Wastes, K/QT-106; Martin Marietta Energy Systems, Inc. Oak Ridge Gaseous Diffusion Plant, Oak Ridge, TN.

Brady, PP.V. and Kozak, M.W., 1995. Geochemical engineering of low level radioactive waste in cementitous environments. Waste Management 15, 293-301.

Brendel, D.F., 1997. A summary of leaks and spills contributing to AX tank farm vadose zone contamination, SGN Eurosys Services Corpp., Report SESC-97-134, Richland, WA. 
Brodda, B.G., and Mingxia, X., 1989. Leaching of Chlorine, Cesium, Strontium, and Technetium from Cement-Fixed Intermediate Level Liquid Waste, Scientific Basis for Nuclear Waste Management, Mat. Res. Soc. Sympp. Proc. 127, pp.418-487.

Buil, M., Revertagat, E. and Oliver, J., 1992. A model of attack of pure water on unsaturated lime solutions in cement. Stabilization and solidification of hazardous, radioactive and mixed wastes, Vol. 2. T. M. Gilliam and C. C. Wiles, ASTM Special Technical Publications (STP) 1123: 227-241.

Byegard, J., Albinsson, G., Skarneamrk, G., and Skalberg, M., 1992, Field and Laboratory Studies on the Reduction and Sorption of Technetium (VII), Radiochimica Acta, 58-9, pp. 239-244.

Carroll, M.A., 1993. Precipitation of Nd-Ca carbonate solid solutions at $25^{\circ} \mathrm{C}$. Geochim. Cosmochim. Acta 57, 3383-3393.

Chu, D., Eriksen, T.E., 1996. Reduction of Pertechnetate by Ferrous Iron in solution: Influence of Sorbed and Precipitated Fe(II), Environmental Science and Technology, v. 30, pp. 22592262

Chu, D. and Eriksen, T.E., 1996. Reduction of pertechnetate by heterogeneous electron transfer from Fe(II)-containing geologic material. Environ. Sci. Technol. 30, 2263-2269.

Dwyer, B.PP., 1997. Demonstration of close-coupled barriers for subsurface containment of buried waste, Sandia National Laboratories. SAND97-1193, Albuquerque, NM.

Eikenberg, J. and Lichtner, PP.C., 1992. Propagation of hyperalkaline cement pore waters into the geologic barrier surrounding a radioactive waste repository. Rotterdam, Balkema.

Eriksen, T.E., Ndalamba, PP., Bruno, J. and Caceci, M., 1992. The solubility of $\mathrm{TcO}_{2} \mathrm{nH}_{2} \mathrm{O}$ in neutral to alkaline solutions under constant $\mathrm{pCO}_{2}$. Radiochim. Acta, 58-9, 67-70.

Fayer, M.J and Walters, T.B., 1995. Estimated recharge rates at the Hanford site. Pacific Northwest Laboratory, Report PNL-10285, Richland, WA.

Felmy, A.R., Rai, D. and Fulton, R.W., 1990. The solubility of $\mathrm{AmOHCO}_{3}(\mathrm{c})$ and the aqueous thermodynamics of the system $\mathrm{Na}^{+}-\mathrm{Am}^{3+}-\mathrm{HCO}_{3}{ }^{-}-\mathrm{OH}^{-}-\mathrm{H}_{2} \mathrm{O}$. Radiochim. Acta 50, $193-204$.

Gee, G.W., Ward, A.L., Gilmore, B.G., Link, S.O., Dennis, G.W. and O'Neil, T.K., 1996. Prototype barrier status report FY 1996. Pacific Northwest Laboratory, Report PNL-11367, Richland, WA.

Grimm, R.E. 1968. Clay mineralogy. New York, McGraw-Hill.

Haworth, A., Sharland, S.M. and Tweed, C.J., 1988. Modeling of the degradation of cement in a 
nuclear waste repository. Mat. Res. Soc. Sympp.

Kincaid, C.T. and others, 1993. Performance assessment of grouted double-shell tank waste disposal at Hanford, Westinghouse Hanford Co. WHC-SD-WM-EE-004, Rev. 0

Kos, S.E., 1997. Vadose zone characterization project at the Hanford tank farms- AX tank farm report. GJO-97-7-TAR

Kosmatka, S.H. and Panarese, W.C., 1990. Design and control of concrete mixtures- 13th edition. Skokie, IL, Portland Cement Assoc.

Lee, J.H., Roy, D.H., Mann, B. and Stahl, D., 1995. Integrated approach to modeling long-term durability of concrete engineered barriers in LLRW disposal facilities. Mat. Res. Soc. Sympp. Proc. 353, 881-889.

Lin, S.K., 1991. Chloride diffusion in a porous cylindrical concrete column. Chem. Eng. Sci. 46, 1189-1192.

Moroni, L.PP. and Glasser, F.PP., 1995. Reactions between cement components and U(VI) oxide. Waste Manag. 15, 243-254.

Pearson, F.J. Jr., Berner, U., and Hummel, W., 1992. NAGRA Themochemical Data Base II. Supplemental Data 05/92, Technical Report 91-18, National Cooperative for the Disposal of Radioactive Waste

Pihlajavaara, S.E., 1992. Estimation of the service life of concrete under different conditions with special reference to radioactive waste repositories. Nucl. Engineer. Design 138, 127133.

Ramsower, D.C., 1997. AX tank farm waste inventory study for the Hanford Tanks Initiative (HTI) Project, Eurysis Services Corpp. EN-RPT-02

Reynolds, T.D. and Morris, R.C., 1997, Landfill capping in the semi-arid west: problems, perspectives and solutions. Conference Proceedings, May 21-22, jackson Lake Lodge, Grand teton National Park, Environmental Science and Research Foundation, Idaho Falls, ID, ESRF-019.

Rumer, R.R. and Mitchell, J.K., 1995. Assessment of barrier containment technologies: a comprehensive treatment for environmental remediation applications. International Containment Technology Workshop. Aug. 29-31, Baltimore, Maryland.

Smith, R.W. and Walton, J.C., 1993. The role of Oxygen Diffusion in the Release of Technetium from Reducing Cementitious Waste Forms, Scientific Basis for Nuclear Waste Management. Mat. Res. Soc. Sympp. Proc. 294, pp.247-252. 
Smyth, J.D., Shade, J.W. and Somasundaram, S., 1992. Assessment of dome-fill technology and potential fill materials for the Hanford single-shell tanks, Pacific Northwest National Laboratory. PNL-8014, Richland, WA.

Tallent, O.K., Mcdaniel, G.D., Del Cul, G.D., Dodson,K.E., and Trotter, D.R., 1988. Immobilization of Technetium and Nitrate in Cement-Based Materials, Scientific Basis for Nuclear Waste Management, Mat. Res. Soc. Sympp. Proc. 112 , pp.23-32.

Treat, R.L. and others, 1995. Feasibility study of tank leakage mitigation using subsurface barriers, Westinghouse Hanford Company. WHC-SD-WM-ES-300 Rev. 1

Vandergaaf, T.T., Ticknor, K.V., and George, I.M., 1984. Reactions Between Technetium in Solution and Iron-Containing Minerals Under Oxic and Anoxic Conditions, in Geochemical Behavior of Disposed Radioactive Waste, ACS Symposium Series 246, Barney, G.S., Navratil, J.D., and Schulz, W.W., eds., March, 20-25, 1983, Seattle Wa., pp.25-66.

Wakeley, L.D. and Ernzen, J.J., 1992. Grout for closure of the demonstration vault at the U.S.DOE Hanford facility, Dept. of Army, Waterways Experiment Station, Vicksburg, MS.

Walton, J.C., Plansky, S.E. and Smith, R.W., 1990. Models for estimation of service life of concrete barriers in low-level radioactive waste disposal. NUREG/CR-5542, NRCWashington, D.C.

Wierenga, PP.J., 1995. Water and solute transport and storage. Handbook of vadose zone characterization and monitoring. L. G. Wilson, L. G. Everett and S. J. Cullen: 41-60.

Williams, C.V. and Ward, D.W., 1997. Verification of the integrity of barriers using gas diffusion, Sandia National Laboratories, SAND97-1425, Albuquerque, NM. 
ruonisoduras

ping [E:

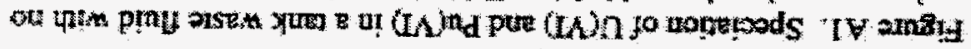
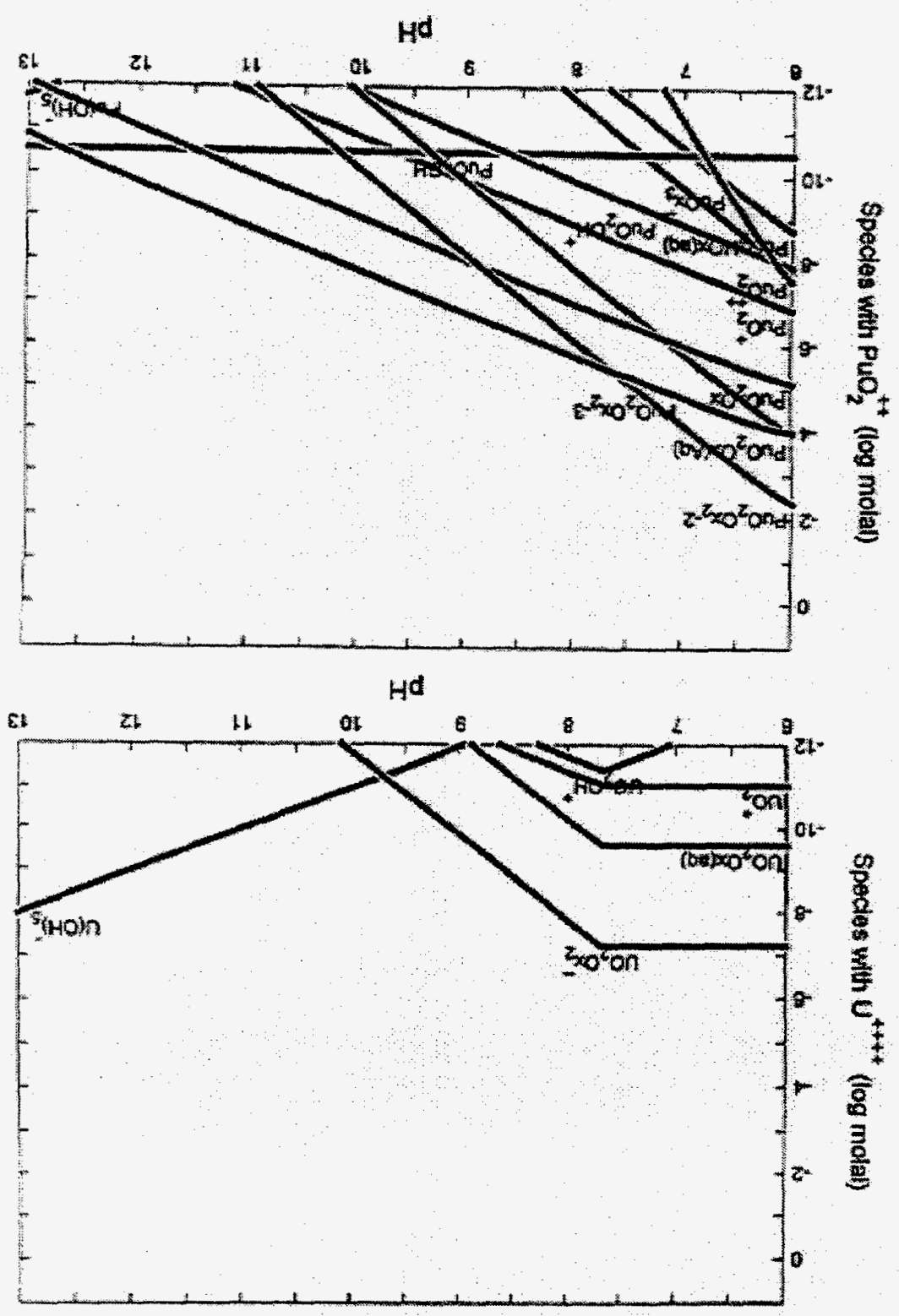

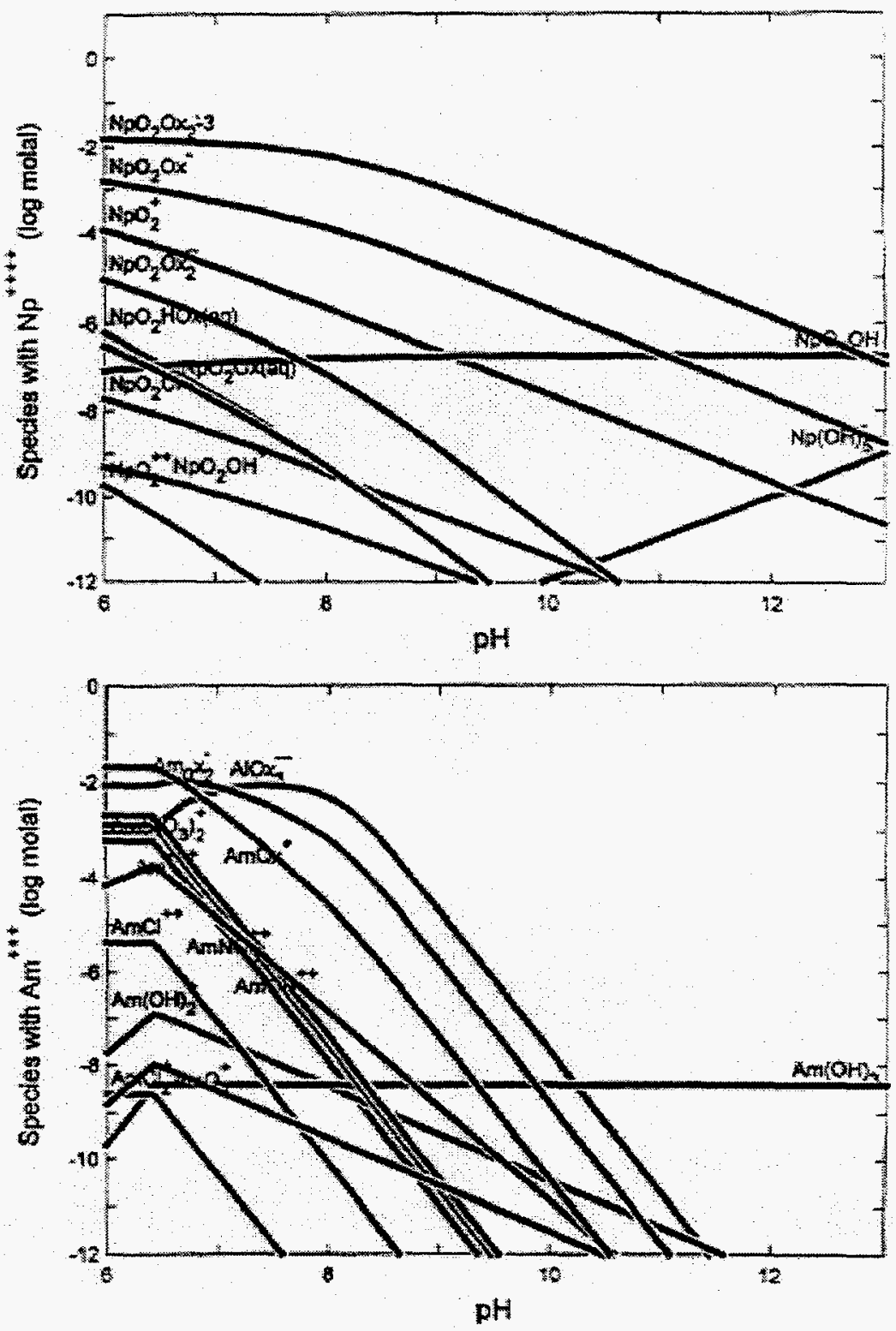

Figure A2. Speciation of $\mathrm{Np}(\mathrm{V})$ and Am(II) in a tank waste flutd with no curbonate or phosphate added (see Tuble 2 and Table 5 for trial fluid composition). 

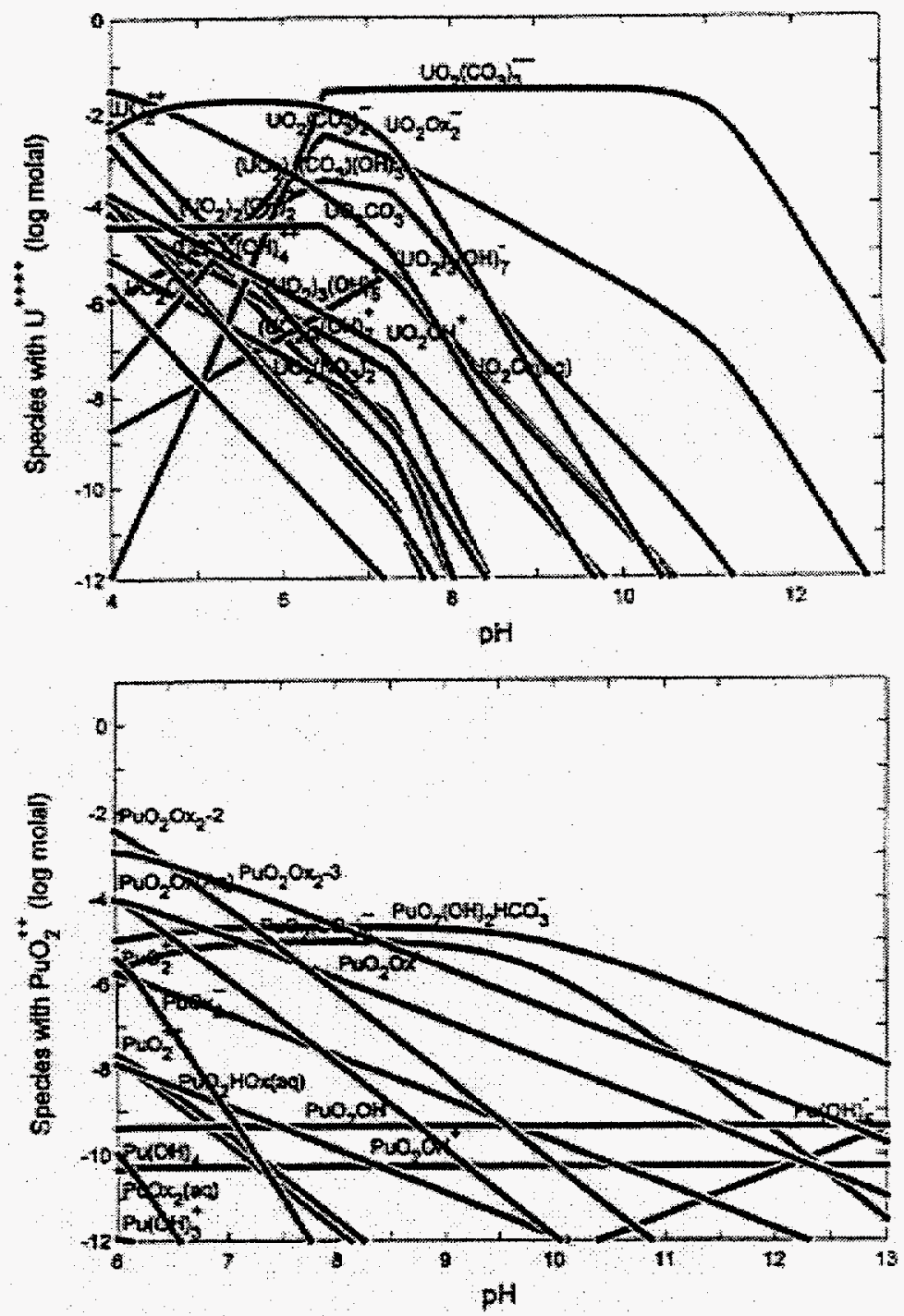

Figure A3. Speciation of U(Y) and Pu(V) in a tank waste thidd with carbonate added but no phosphate see. Table 2 and Table 5 for trial fiud composition). 

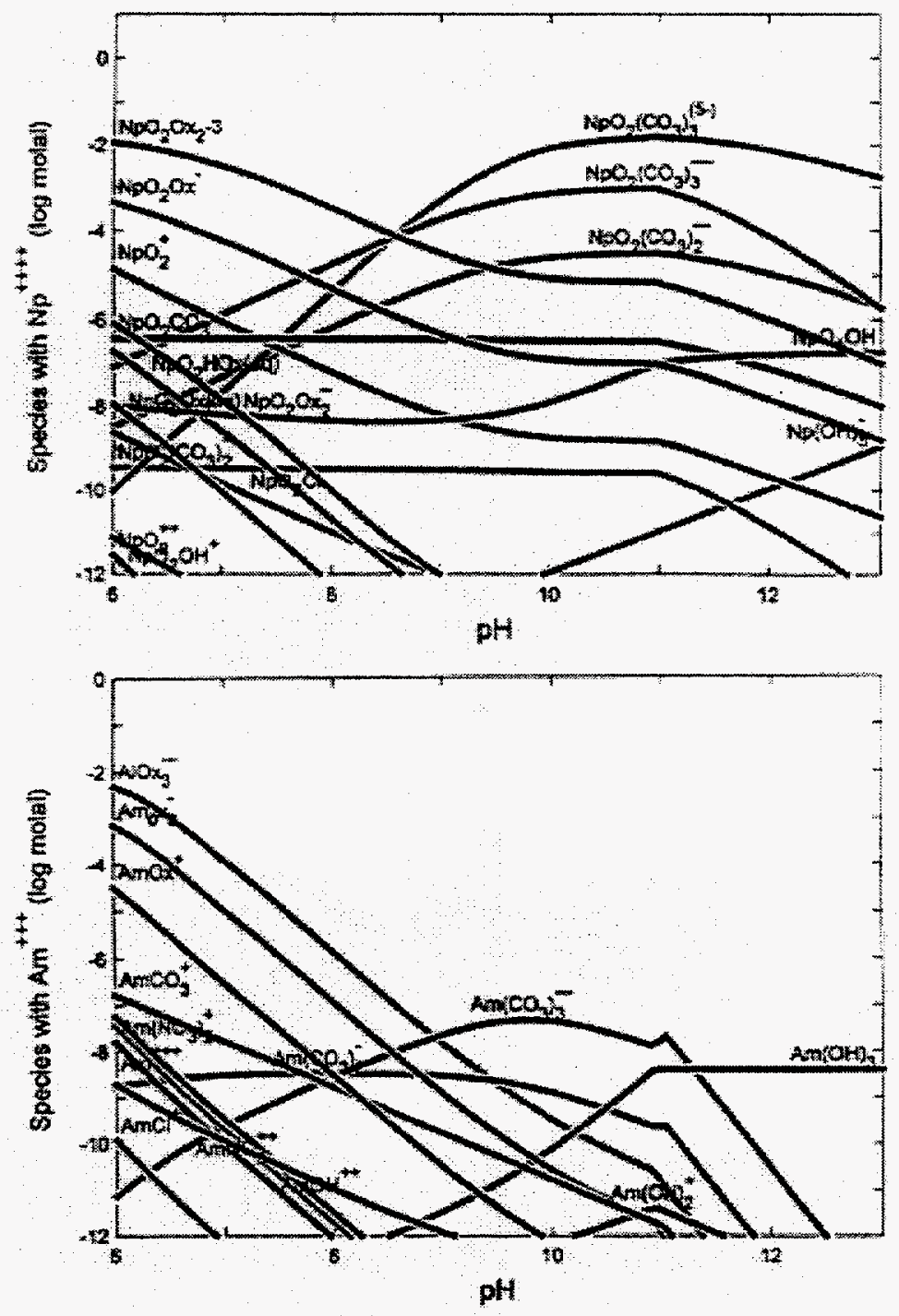

Frgure A4. Speciation of $\mathrm{NP}(\mathrm{V})$ and Am(IT) in a tank wate flude with carbonate added but no phosphate isee Table 2 and Table 5 for trad Fud composition. 

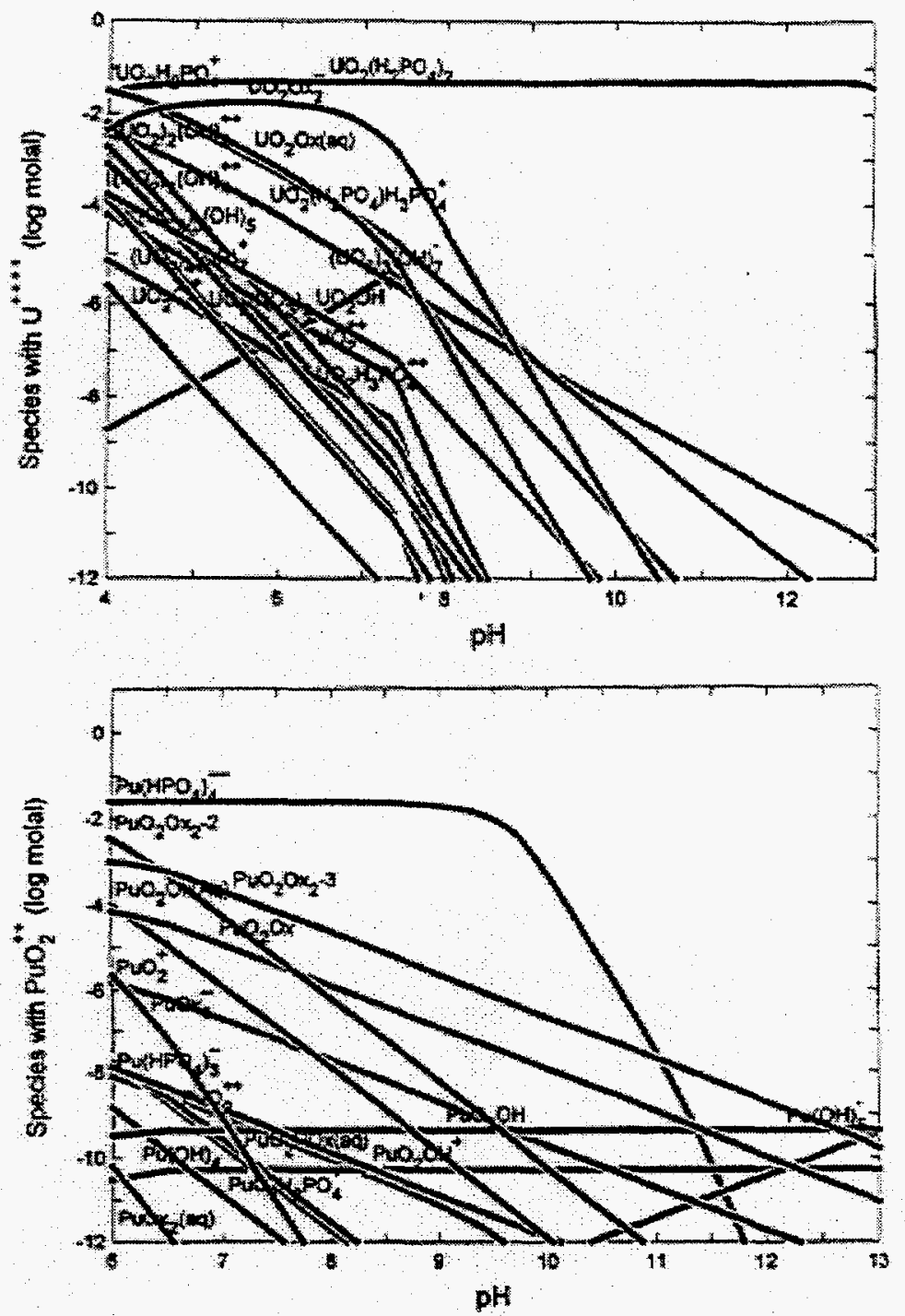

Figure A5. Speciation of U(VI and Pu(VD in a tank waste fluid with phosplinate added but no cartonate (see Table 2 and Table 5 for trial fluid composition). 

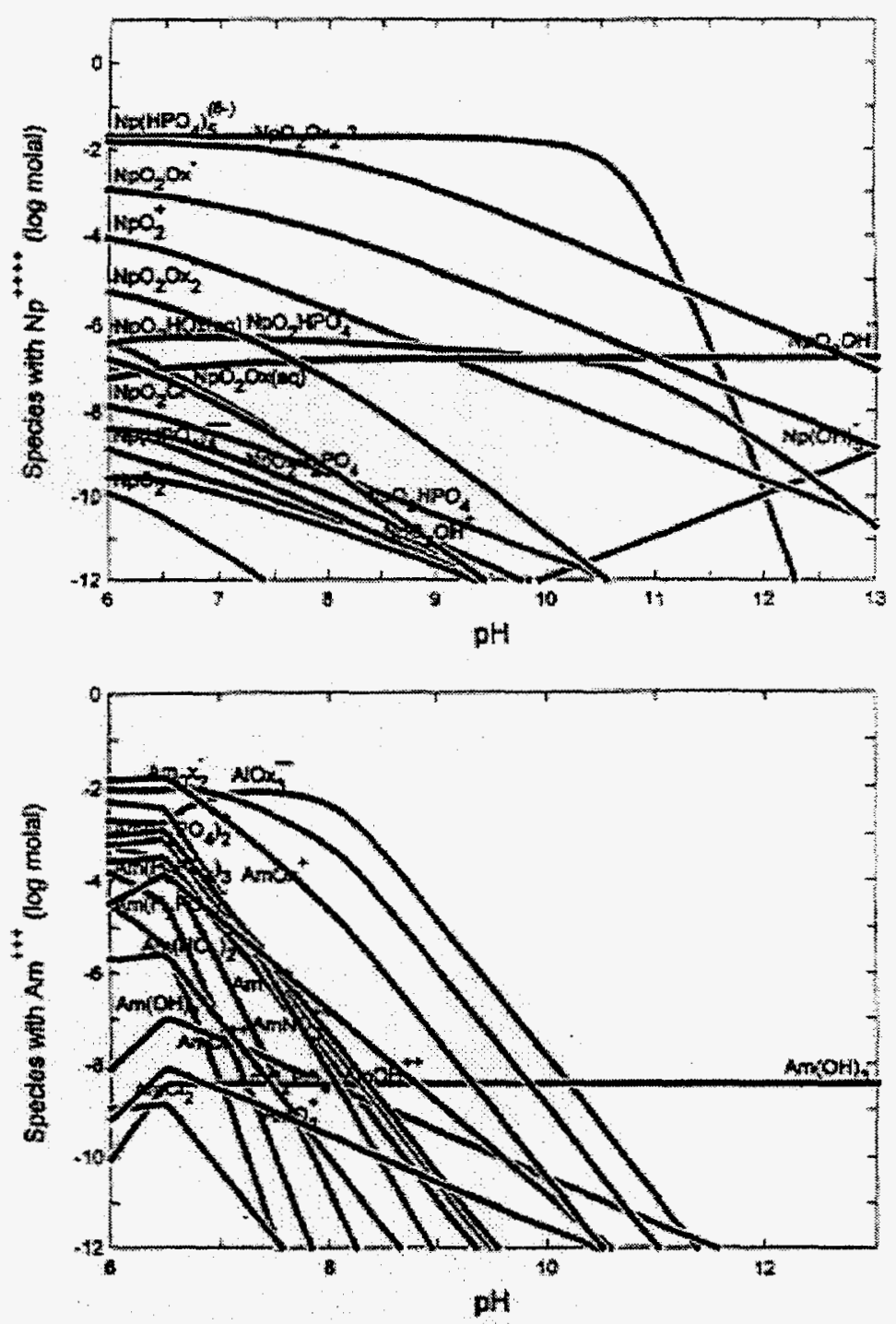

Figure A6. Speciation of $\mathrm{Np}(\mathrm{V})$ and $\mathrm{Ar}$ (III) in a tank waste fluid with phosphate added but no carbonate (see Table 2 and Table 5 for srial fluid composition?. 

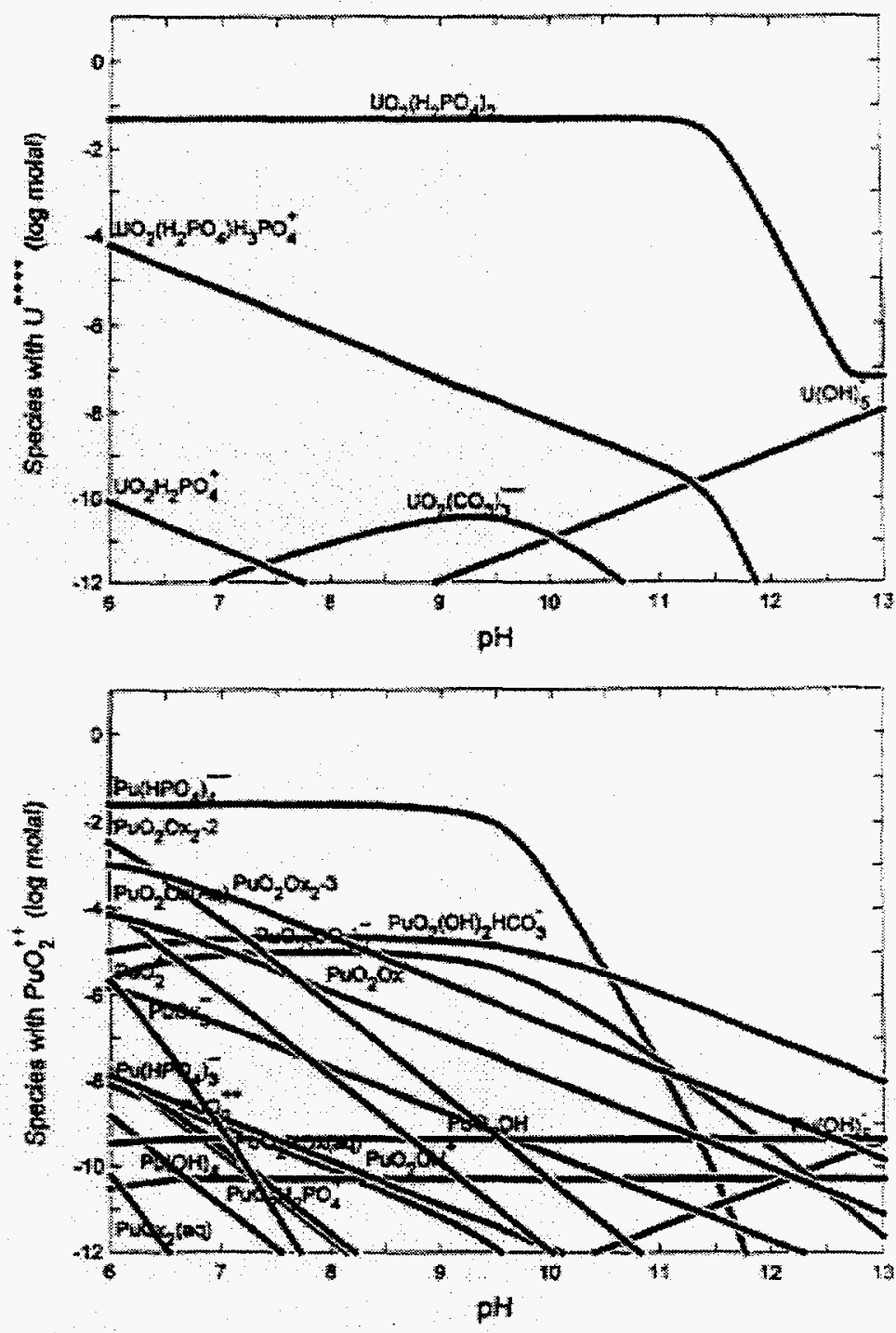

Figure A7. Speciation of U(VT) and PU(VD in a tank waste fluid with both phosphate and carbonste atded (sce Table 2 and Table $S$ for trial fluid composition). 

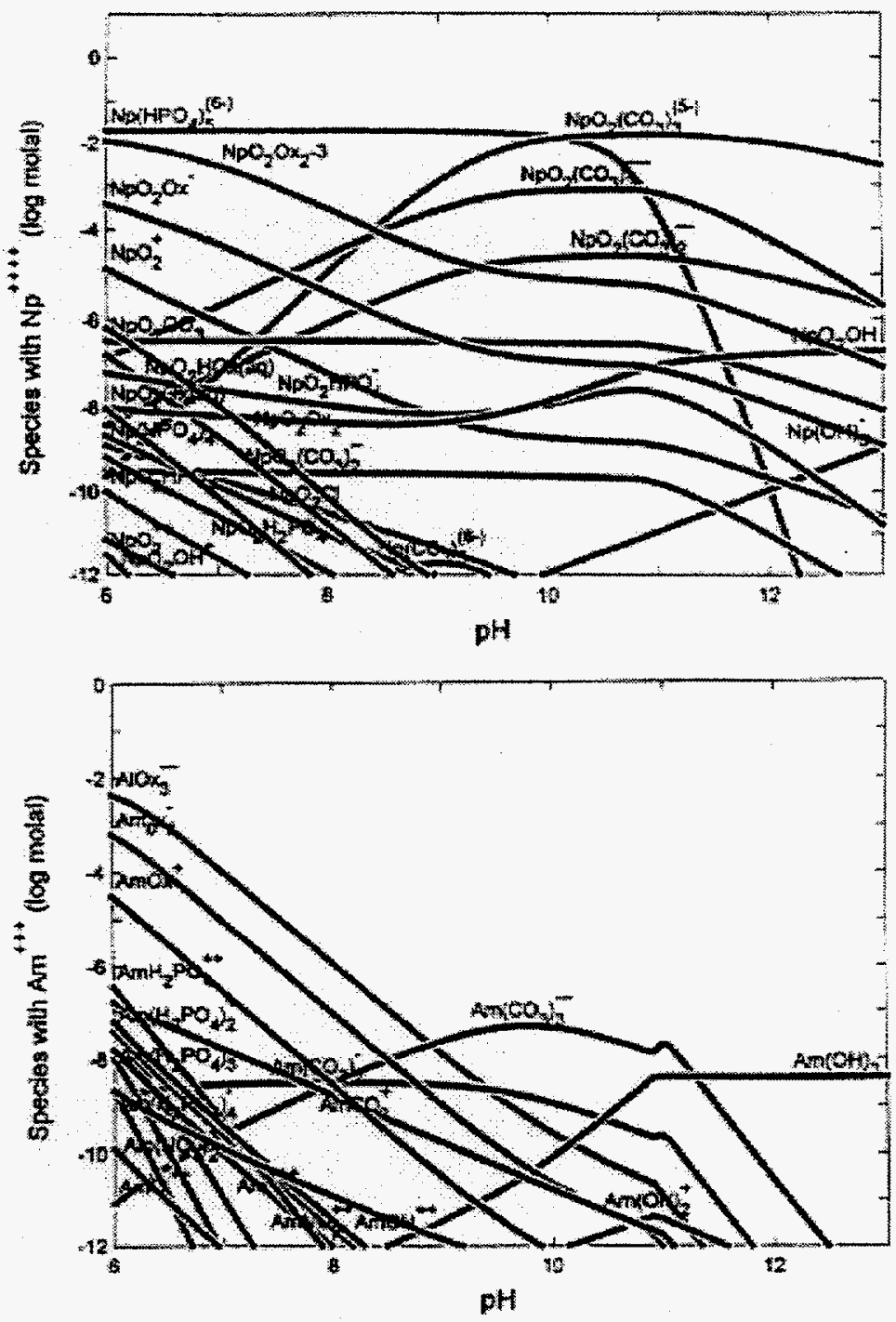

Figure A8. Speciation of NpY and Am(TH) in a tank waste luid with phosphate and carbonate added (soc Table 2 and Table 5 for trial flisid compesitiony. 


\section{APPENDIX B. RADIOACTIVE RELEASE MODELS}

\section{Scenario I.}

Tank filled with soil. No getters. Calculate time required to displace sludge fluid (assuming no ponding).

\begin{tabular}{|c|c|c|c|c|c|c|}
\hline & & $\mathrm{RCR}$ & Cap & & & \\
\hline & & $\underline{\underline{N o}}$ & Yes & & & \\
\hline Tank radius & $(\mathrm{cm})$ & 1143 & 1143 & & & \\
\hline Tank area & $\left(\mathrm{m}^{2}\right)$ & 410 & 410 & & & \\
\hline Infiltration rate $v(f)$ & (mm/day) & $1.8 \mathrm{E}-01$ & $9.5 \mathrm{E}-05$ & Assumptions & & \\
\hline & (cm/day) & $1.8 \mathrm{E}-02$ & $9.5 \mathrm{E}-06$ & Sludge height & $\mathrm{cm}$ & 6.5 \\
\hline & $\left(\mathrm{m}^{3} /\right.$ day $)$ & 7.4E-02 & $3.9 \mathrm{E}-05$ & Sludge vol. after $90 \%$ removal & $\left(\mathrm{m}^{3}\right)$ & 26.5 \\
\hline Waste vol. & $\left(\mathrm{cm}^{3}\right)$ & $2.7 \mathrm{E}+07$ & $2.7 \mathrm{E}+07$ & Sludge porosity $(\sigma)$ & $(\%)$ & 0.5 \\
\hline Fluid vol. & $\left(\mathrm{m}^{3}\right)$ & 13.3 & 13.3 & Soil density $(\sigma)$ & $\left(\mathrm{g} / \mathrm{cm}^{3}\right)$ & 1.96 \\
\hline Displ. T/ fluid vol & (days) & 179 & 339993 & Soil porosity $(\theta)$ & $(\%)$ & 0.26 \\
\hline Displ. T/ fluid vol & (yrs) & 0.49 & 931 & $\sigma / \theta$ & & 7.5 \\
\hline
\end{tabular}

\begin{tabular}{|c|c|c|c|}
\hline \multicolumn{4}{|c|}{ Retardation Factors $\left(\mathrm{K}_{\mathrm{d}}\right)$ For Important Radionuclides } \\
\hline Element & Hydroxyapatite & Magnetite & Clay Minerals \\
\hline Tc & 0 & 100 & 20 \\
\hline$\overline{\mathrm{U}}$ & 0 & 100 & $\overline{1000}$ \\
\hline $\mathrm{Pu}$ & 1000 & 0 & 10000 \\
\hline $\mathrm{Am}$ & 50000 & 0 & 10000 \\
\hline $\mathrm{Np}$ & 60000 & 0 & 500 \\
\hline
\end{tabular}




\section{Scenario II.}

Tank filled with soil. Getters added. Calculate time required to displace radionuclides (assumes no ponding)

from the following expression:

$$
\frac{\mathrm{v}(\mathrm{i})}{\mathrm{v}(\mathrm{f})}=\frac{1}{1+\frac{\sigma}{\theta} K_{D}}
$$

where $v(i)$ is the rate of radionuclide transport and $v(f)$ is the fluid flow rate.

Note that Kd's for americium and neptunium have been adjusted down by a factor of 10 to accommodate the expected drop in retardation at $\mathrm{pH} 13$.

\begin{tabular}{|c|c|c|c|c|c|c|c|}
\hline \multirow[t]{2}{*}{ Americium $\mathbf{K}_{\mathrm{D}}$} & \multirow[t]{2}{*}{5000} & \multicolumn{2}{|c|}{ RCRA Cap } & \multirow[t]{2}{*}{ Neptunium $K_{D}$} & \multirow[t]{2}{*}{6000} & \multicolumn{2}{|c|}{ RCRA Cap } \\
\hline & & No & Yes & & & No & Yes \\
\hline Infiltration rate $v(f)$ & (mm/day) & $1 . \overline{8 \mathrm{E}-01}$ & $\overline{9.5 \mathrm{E}-05}$ & Infiltration rate $\mathrm{v}(\mathrm{f})$ & (mm/day) & $1 . \overline{8 \mathrm{E}-01}$ & $9.5 \mathrm{E}-05$ \\
\hline Radionuclide rate $v(i)$ & (mm/day) & $4.8 \mathrm{E}-06$ & $2.5 \mathrm{E}-09$ & Radionuclide rate $\mathrm{v}(\mathrm{i})$ & (mm/day) & $4.0 \mathrm{E}-06$ & $2.1 \mathrm{E}-09$ \\
\hline Time to remove & (days) & $6.8 \mathrm{E}+06$ & $1.3 E+10$ & ime to remove & (days) & $8.1 E+06$ & $1.5 \mathrm{E}+10$ \\
\hline Time to $r$ & (yrs) & $1.9 \mathrm{E}+04$ & $3.5 \mathrm{E}+07$ & Time to remove & (yrs) & $2.2 \mathrm{E}+04$ & $4.2 \mathrm{E}+07$ \\
\hline \multirow[t]{2}{*}{ Plutonium $K_{\mathrm{D}}$} & \multirow[t]{2}{*}{1000} & \multicolumn{2}{|c|}{ RCRA Cap } & \multirow{2}{*}{ Uranium $K_{D}$} & \multirow[t]{2}{*}{100} & \multicolumn{2}{|c|}{ RCRA Cap } \\
\hline & & $\underline{\text { No }}$ & Yes & & & No & Yes \\
\hline ate $v(f)$ & (mm/day) & $1 . \overline{8 \mathrm{E}-01}$ & $9 . \overline{\mathrm{E}-05}$ & ion rate $v(f)$ & (mm/day) & $1.8 \mathrm{E}-01$ & $9.5 \mathrm{E}-05$ \\
\hline Radionuclide rate $\mathrm{v}(\mathrm{i})$ & $(\mathrm{mm} /$ day $)$ & $2.4 \mathrm{E}-05$ & $1.3 \mathrm{E}-08$ & Radionuclide rate $\mathrm{v}(\mathrm{i})$ & $(\mathrm{mm} /$ day $)$ & 2.4E-04 & $1.3 \mathrm{E}-07$ \\
\hline Time to remove & (days) & $1.4 \mathrm{E}+06$ & $2.6 \mathrm{E}+09$ & Time to remove & (days) & $1.4 \mathrm{E}+05$ & $2.6 \mathrm{E}+08$ \\
\hline Time to remove & (yrs) & $3.7 \mathrm{E}+03$ & $7.0 \mathrm{E}+06$ & Time to remove & (yrs) & $3.7 \mathrm{E}+02$ & $7.0 E+05$ \\
\hline
\end{tabular}




\section{Scenario III.}

Tank filled with grout. No getters added. Assume $1 \mathrm{~m}$ crack grid with apertures $>0.001 \mathrm{~cm}$.

Radionuclide solubility at $\mathrm{pH} 13$ (from React)

\begin{tabular}{|c|c|c|c|c|}
\hline & \multicolumn{2}{|c|}{ Grouting } & \multirow[b]{2}{*}{ Ratio } & \multirow[b]{2}{*}{$\mathrm{mol}$ in sol ${ }^{\mathrm{n}}$} \\
\hline & Prior & After & & \\
\hline $\mathrm{Pu}$ & $7.0 \mathrm{E}-06$ & $2.5 \mathrm{E}-12$ & $2.8 \mathrm{E}+06$ & $3.3 \mathrm{E}-08$ \\
\hline$U$ & $6.0 \mathrm{E}-03$ & $1.0 \mathrm{E}-17$ & $6 E+14$ & $1.3 \mathrm{E}-13$ \\
\hline $\mathrm{Np}$ & $3.0 \mathrm{E}-06$ & $1.0 \mathrm{E}-07$ & 30 & $1.3 \mathrm{E}-03$ \\
\hline $\mathrm{Am}$ & $4.0 \mathrm{E}-06$ & $4.0 \mathrm{E}-09$ & 1005 & $5.3 \mathrm{E}-05$ \\
\hline
\end{tabular}

\section{Scenario IV.}

Tank filled with grout. Assume $1 \mathrm{~m}$ crack grid with apertures $<0.001 \mathrm{~cm}$. Assume $1 \mathrm{~m}$ thick skirt

$\begin{array}{llll}\text { Diffusion coef. (D) } \quad \mathrm{cm}^{2} / \mathrm{s} & 1 . \mathrm{E}-08 & \\ & & & \\ \text { Calculated flux } & \mathrm{mol} / \mathrm{cm}^{2} \mathrm{~s} & 2.5 \mathrm{E}-25 & \mathrm{Pu} \\ & & 1.0 \mathrm{E}-30 & \mathrm{U} \\ & 1.0 \mathrm{E}-20 & \mathrm{~Np} \\ & 4.0 \mathrm{E}-22 & \mathrm{Am}\end{array}$

Flux $=\mathrm{D}\left(\mathrm{C}_{1}-\mathrm{C}_{2}\right) / \mathrm{L}$

$\mathrm{C}_{1}=$ radionuclide conc. in tank after grouting

$\mathrm{C}_{2}=$ radionuclide conc. at bottom of skirt (assumed zero)

$\mathrm{L}=$ path length, defined as $100 \mathrm{~cm}$ 


\section{Distribution}

2 MS 0871

S. D. Balsley, 14405-1

10 MS 0750

J. L. Krumhansl, 6118

3 MS 0750

D. J. Borns, 6116

1 MS 0750

H. R. Westrich, 6118

1 MS 9018

Central Technical Files, 8940-2

$2 \quad$ MS 0899

Technical Library, 4916

2 MS 0619 Review and Approval Desk, 12690

For DOE/OST I 